
\title{
$\mathrm{UNLV}||_{\text {LIBRARIES }}^{\mathrm{UNIVRSTY}}$
}

UNLV Retrospective Theses \& Dissertations

$1-1-1997$

\section{Yield management and its practical application in hotels}

Jeffrey M. Caneen

University of Nevada, Las Vegas

Follow this and additional works at: https://digitalscholarship.unlv.edu/rtds

\section{Repository Citation}

Caneen, Jeffrey M., "Yield management and its practical application in hotels" (1997). UNLV Retrospective Theses \& Dissertations. 3315.

http://dx.doi.org/10.25669/cgb2-kn6r

This Thesis is protected by copyright and/or related rights. It has been brought to you by Digital Scholarship@UNLV with permission from the rights-holder(s). You are free to use this Thesis in any way that is permitted by the copyright and related rights legislation that applies to your use. For other uses you need to obtain permission from the rights-holder(s) directly, unless additional rights are indicated by a Creative Commons license in the record and/ or on the work itself.

This Thesis has been accepted for inclusion in UNLV Retrospective Theses \& Dissertations by an authorized administrator of Digital Scholarship@UNLV. For more information, please contact digitalscholarship@unlv.edu. 


\section{INFORMATION TO USERS}

This manuscript has been reproduced from the microfilm master. UMI films the text directly from the original or copy submitted. Thus, some thesis and dissertation copies are in typewriter face, while others may be from any type of computer printer.

The quality of this reproduction is dependent upon the quality of the copy submitted. Broken or indistinct print, colored or poor quality illustrations and photographs, print bleedthrough, substandard margins, and improper alignment can adversely affect reproduction.

In the unlikely event that the author did not send UMI a complete manuscript and there are missing pages, these will be noted. Also, if unauthorized copyright material had to be removed, a note will indicate the deletion.

Oversize materials (e.g., maps, drawings, charts) are reproduced by sectioning the original, beginning at the upper left-hand comer and continuing from left to right in equal sections with small overlaps. Each original is also photographed in one exposure and is included in reduced form at the back of the book.

Photographs included in the original manuscript have been reproduced xerographically in this copy. Higher quality $6 " \times 9$ " black and white photographic prints are available for any photographs or illustrations appearing in this copy for an additional charge. Contact UMI directly to order.

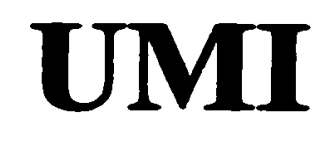

A Bell \& Howell Information Company 300 North Zeeb Road, Ann Arbor MI 48106-1346 USA

$313 / 761-4700 \quad 800 / 521-0600$ 


\title{
YIELD MANAGEMENT AND ITS PRACTICAL
}

\section{APPLICATION IN HOTELS}

by

Jeffery M. Caneen

A thesis submitted in partial fulfillment of the requirements for the degree of

\author{
Master of Science \\ in
}

Hotel Administration

\author{
William H. Harrah College of Hotel Administration \\ University of Nevada, Las Vegas \\ August 1997
}


OMI Number: 1387120

UMI Microform 1387120

Copyright 1997, by UMI Company. All rights reserved.

This microform edition is protected against unauthorized copying under Title 17, United States Code.

\section{UMI \\ 300 North Zeeb Road \\ Ann Arbor, MI 48103}


(C1997 Jeffery M. Caneen

All Rights Reserved 
The Thesis of Jeffery M. Caneen for the degree of Master of Science in Hotel Administration is approved.
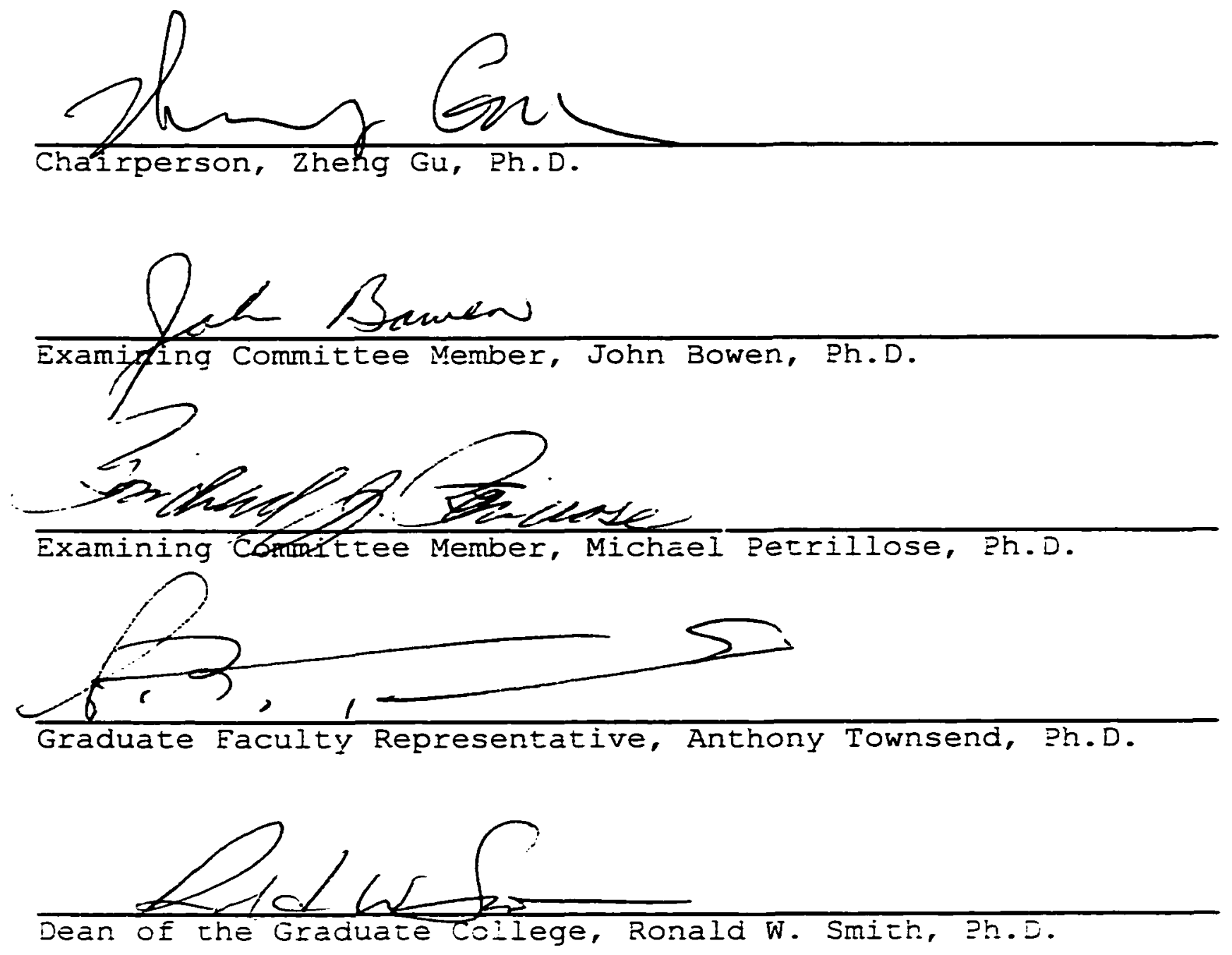

\author{
University of Nevada, Las Vegas \\ August 1997
}




\begin{abstract}
Yield management is an approach to pricing that is often used by industries in which the marginal production cost is relatively high, while the marginal sales cost is relatively low. The hotel industry meets this criteria. Industry publications demonstrate a keen interest in the revenue enhancing potential of yield management, but there has been little research on the extent to which this pricing technique is actually utilized by hotel general managers.

This research tests the proposition that there are eight basic elements of yield management in hotels. The degree to which yield management is practiced is indicated by the extent that these eight elements are in place. It was found that there is a positive relationship between a manager's perception of his or her own yield management utilization and the extent to which the 8 elements are used. It was also found, however, that while $76.9 \%$ of hotels claim to be utilizing yield management techniques extensively, very few are using all of the basic elements in their efforts to maximize revenue.
\end{abstract}


ABSTRACT . . . . . . . . . . . . . . . . . .

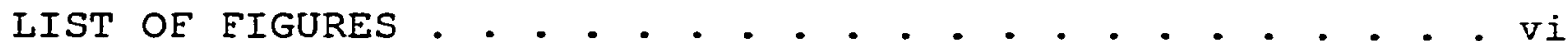

ACKNOWLEDGMENTS . • • . . . . . . . . . . . . . . . . vii

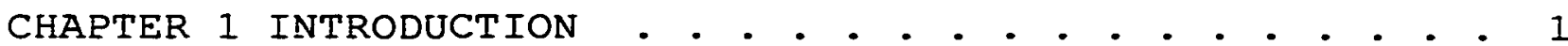

History . . . . . . . . . . . . . . . . . . . 2

Definition...................... . 5

Problem Statement . . . . . . . . . . . . . . 7

Research Hypotheses . . . . . . . . . . . . . . 9

Contribution of This study . . . . . . . . . . . . . 11

Delimitations . . . . . . . . . . . . . . . . 11

Organization of This Study . . . . . . . . . . . . . . 11

CHAPTER 2 LITERATURE REVIEW . . . • . . . . . . . . . 13

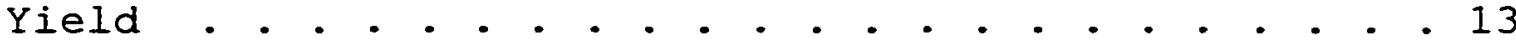

Elasticity of Demand . . . . . . . . . . . . . 17

Segmentation . . . . . . . . . . . . . . . . 19

Booking Patterns . . . . . . . . . . . . . . 22

Demand Patterns . . . . . . . . . . . . . . 24

Sales, Denials and Regrets... . . . . . . . . . 24

Forecasting . . . . . . . . . . . . . . . . . 25

Pricing and Marginal Cost . . . . . . . . . . 28

Optimal Allocation of Room Inventory... . . . . . 31

Summary . . . . . . . . . . . . . . . 35

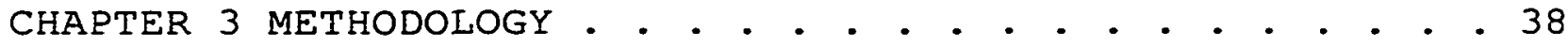

Questionnaire Design . . . . . . . . . . . . . 38

Survey Administration and Sample Selection . . . . 41

Data Collection . . . . . . . . . . . . . . 41

Data Analysis . . . . . . . . . . . . . . 50

Hypothesis Testing . . . . . . . . . . . . 50

Summary . . . . . . . . . . . . . . . 54

CHAPTER 4 RESEARCH RESULTS . . . . . . . . . . . . . . 55

Survey Data . . . . . . . . . . . . . . . . 55

Hypothesis Testing. . . . . . . . . . . . 67

Yield Management . . . . . . . . . . . 68

Willingness to Pay . . . . . . . . . . . . 69

Booking Patterns . . . . . . . . . . . 70

Demand Patterns............. . . 71

Sales.................... . 72

Denials and Regrets... . . . . . . . . 73

Eorecasting. . . . . . . . . . . . . . 74

Price Floor. . . . . . . . . . . . . 75

iv

Reproduced with permission of the copyright owner. Further reproduction prohibited without permission. 


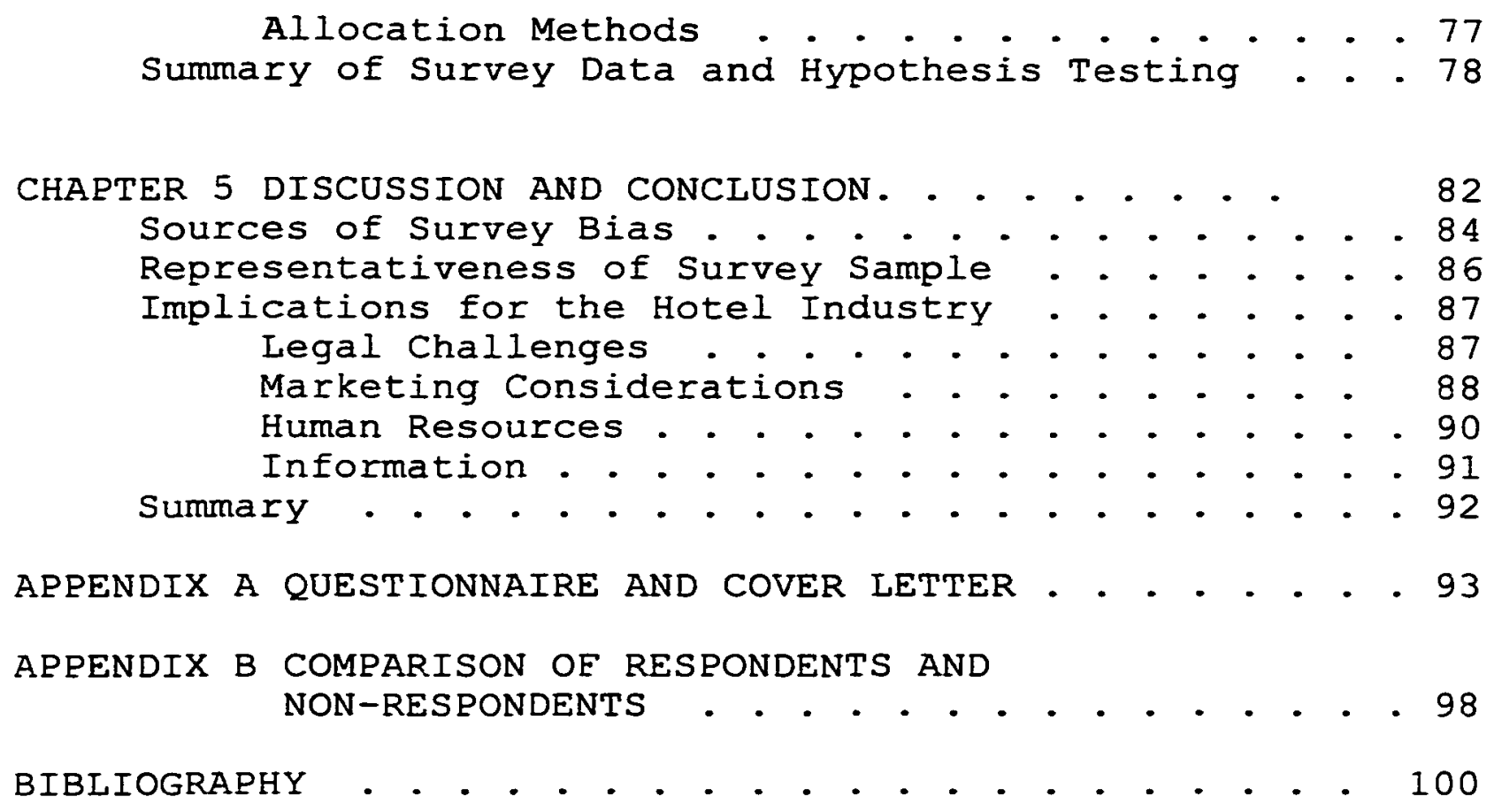


Table 1 Equivalent Yield Combinations . . . . . . . . . 14

Table 2 Equivalent REVPAR Combinations . . . . . . . . . 14

Table 3 Contribution Margin by Segment . . . . . . . . . 17

Table 4 Sample segment Allocation . . . . . . . . . . . 32

Table 5 Response Rate by State . . . . . . . . . . . . . 43

Table 6 Response Rate by Size of Hotel . . . . . . . . . 45

Table 7 Response Rate by Type of Organization. . . . . . 45

Table 8 Response Rate by Service Level . . . . . . . . . 46

Table 9 Response Rate by Primary Market . . . . . . . . 46

Table 10 Response Rate by Average Daily Rate . . . . . . 47

Table 11 Response Rate by Occupancy . . . . . . . . . . 48

Table 12 Response Rate by G.M. Experience . . . . . . . . 48

Table 13 Response Rate by G.M. Education . . . . . . . 49

Table 14 Responses to Questions 13 and 14 . . . . . . . 56

Table 15 Responses to Question 23, Option 1. . . . . . . 56

Table 16 Responses to Question 23, Option 2 . . . . . . . 57

Table 17 Responses to Question 23, Option 3. . . . . . . 57

Table 18 Responses to Question 23, Option 4. . . . . . . 58

Table 19 Responses to Question 23, Option 5 . . . . . . . 58

Table 20 Responses to Question 25 . . . . . . . . . . . . 60

Table 21 Responses to Question 26 . . . . . . . . . . . . 60

Table 22 Responses to Question 27 . . . . . . . . . . . . 61

Table 23 Responses to Question 28. . $^{2}$. . . . . . . . . . . 61

Table 24 Responses to Question 29. . $^{2}$. . . . . . . . . . 62

Table 25 Responses to Question 30 . . . . . . . . . . . . 62

Table 26 Responses to Question 31 . . . . . . . . . . . . 63

Table 27 Responses to Question 32 . . . . . . . . . . . . 63

Table 28 Responses to Question 33 . . . . . . . . . . . 64

Table 29 Responses to Question 34 . . . . . . . . . . . 64

Table 30 Responses to Question 35 . . . . . . . . . . . . 65

Table 31 Number of YM Essential Elements Used . . . . . . 66

Table 32 Essential Elements Used by GM's Perception . . 68

Table 33 Willingness to Pay by GM's Perception . . . . . 69

Table 34 Booking Pattern by GM's Perception . . . . . . . 70

Table 35 Demand Pattern by GM's Perception . . . . . . 71

Table 36 Sales by GM's Perception . . . . . . . . . . . 72

Table 37 Denials and Regrets by GM's Perception . . . . 73

Table 38 Eorecasting by $\mathrm{GM}^{\prime} \mathrm{s}$ Perception . . . . . . . . . 74

Table 39 t-test for ratio of Marginal Cost to Price Floor 76

Table 40 Optimal Allocation by GM's Perception . . . . 77

Table 41 Summary of Hypothesis Testing . . . . . . . . . 81

Table 42 Ratio of YM Practitioners Who Use Each Element .84

Table 43 Comparison With Other Survey Data . . . . . . 87

Table 44 Elements Used by Type of Respondent . . . . . 99

vi

Reproduced with permission of the copyright owner. Further reproduction prohibited without permission. 


\section{ACKNOWLEDGMENTS}

I wish to thank Dr. Zheng Gu for his assistance in guiding me through this research. He has been all that one could ask for in an advisor: patient, insightful, and goodhumored. I also want to thank the other members of my examining committee: Dr. John Bowen, Dr. Mike Petrillose and Dr. Anthony Townsend for their helpful recommendations.

In addition, I would like to express my appreciation to many informal advisors who helped me greatly by way of providing support and encouragement. Chief among these are Prof. Andy Nazarechuk, Dr. Bob Bosselman, Dr. Gail Sammons, and Dr. Pearl Brewer.

vii 
CHAPTER 1

\section{INTRODUCTION}

Yield is a term that has been appropriated from agriculture. A farmer has a fixed amount of acreage from which he will attempt to maximize output or "yield." He cannot easily add acreage to his farm, so he uses all of his genius to increase the yield from his more-or-less fixed capacity. Crop selection and rotation, cultivation methods, genetic engineering of plants and animals, fertilizer and chemical technologies have all been developed to increase the farmer's yield. Entire scientific discipiines have evolved to address this basic characteristic of farming: The productive capacity is ultimately fixed, and the only practical method of increasing output is to increase the "yield" from each acre.

other industries, particularly service industries, also have what amounts to fixed capacity. Kimes (1990, p. 189) has shown that "When service firms are constrained by capacity ... financial success is often a function of management's ability to use capacity efficiently". In the hotel industry, the term "yield management" is used to refer to a process of maximizing the profitability of a hotel 
through manipulation of its pricing and booking policies. The goal of a yield management system is to consistently maintain the highest possible revenue from a given amount of room capacity.

The crux of the yield management problem is that for businesses like hotels, with very high capital investments and low variable costs, increasing revenue is essentially equivalent to increasing profits (Griffin, 1994). The cost of adding additional rooms is very high, while the cost of renting an additional room is very low. Like the farmer, the hotelier uses all of his efforts to maximize the yield (in dollars) from each room.

This is not a new insight, although it has a new name (yield management) and it has received new attention resulting from the implications of computer technology and the experience of the airline industry in adjusting to a suddenly deregulated environment.

\section{History}

While a kind of yield management was practiced by both the airline industry and the hotel industry in the 1950's, the techniques employed were generally limited to intentional over booking. With experience, no-shows and walk-ins could be predicted by season and day-of-week with some accuracy. This allowed managers to over book by a 
predetermined amount and by so doing, realize higher occupancy levels and resulting revenues.

In the 1980's, two developments converged to make advanced yield management techniques both possible and necessary: affordable computer technology and airline deregulation.

Sudden deregulation in the late 1970's created a suicidal competition for market share among U.S. domestic air carriers. Before deregulation, the airlines commonly divided their product into two rate classes, coach and first-class; the two being distinguished by a tangible difference in accommodations and level of service. For a given flight there was one fare for coach and one fare for first-class. In their efforts to compete in the deregulated environment, the airlines made cut after cut in these rates, and as a result, the domestic airline industry lost more money between 1976 and 1987 than it had made since its beginning (Reed, 1993).

By the mid-eighties, the situation had gotten so bad that most airplanes could be filled to capacity with paying passengers and the airline would still lose money on the flight. The dilemma is illustrated by the following example: If 100 people were willing to pay $\$ 100$ each for a flight, cutting the rate to $\$ 75$ would force the airline to attract 34 additional people (a total of 134 passengers) before its 
revenues for that flight would exceed what they would have been had the fare remained $\$ 100$. Because airlines nearly always match their competitors' lowest fares, the odds of generating a $34 \%$ increase in demand with a $25 \%$ price cut are incalculably high (Reed, 1993).

Bob Crandall, CEO of American Airlines, created a strategy to change this formula for bankruptcy. First of all, he developed "Super Saver" fares: discounts with restrictions that made them unattractive to business travelers and others who were judged willing and able to pay higher fares. Then complex, real-time calculations were made, and repeated continually until the time of departure, to forecast the optimum mix of full-fare and discount tickets to sell for any given flight. These iterative calculations required massive computer power. American Airlines called this strategy "yield management."

Crandall assessed the impact of yield management on his airline in 1991 when he said:

We estimate that yield management has generated $\$ 1.4$ billion in incremental revenue in the last three years alone. This is not a one time benefit. We expect to see Yield Management generate at least $\$ 500$ million each year for the foreseeable future (Griffin, 1994, p. 63). 
In 1991 American airlines received the Eranz Edelman Award of Management Science Achievement for the development of its yield management system (Griffin, 1994).

In the late 1980's the hotel industry, taking note of the success of yield management in the airline industry, began to implement some of the same techniques. While yield management has been credited with revenue increases of 2-5\% in "situations of extremely high demand and very limited capacity" (Gallacher, 1995, p. 41), its advantages are not as apparent when supply exceeds demand. Just as the hotel industry was becoming aware of yield management, it began to suffer from severe overbuilding and excess capacity. While there was a lot of talk and research about hotel yield management, it was deemed to be largely impractical until the industry began an economic turnaround in 1993.

\section{Definition}

Today, yield management is a popular concept in the hotel industry, but there are fundamental disagreements within the industry concerning almost everything about it. Not least among these disagreements is that regarding the very definition and meaning of the term itself. As Lieberman (1993, p. 34) discovered: "if you ask ten hoteliers what it is, you are apt to get at least five, and possibly ten, different answers." 
A popular definition of yield management is the one used by American Airlines. They define the objective of Yield Management as: "to maximize passenger revenue by selling the right seats to the right customers at the right time" (Weatherford, 1992, p. 832).

Along the same lines, Nykiel (1989, p. 26) defined Yield Management as "charging a different rate for the same service to a different individual." These definitions refer to a general attempt to choose between available business in such a way as to sell each room to the customer willing to pay the highest price for it. But is this anything new? At least one researcher thinks not. Lieberman concluded that "yield management does not try to accomplish anything different from what hoteliers have always tried to do" (Lieberman, 1993, p. 36).

Griffin concluded that "'yield management' has been used in the lodging industry for almost any process that attempts to increase the business's profitability" (Griffin, 1994, p. 33). Another researcher agreed with Griffin but maintained that "what makes contemporary Yield Management so different from traditional pricing practices is the frequency and scope of the decision making process" (Relihan, 1989, p. 41). In other words, the objective is the same as it has always been, but Yield Management techniques are more sophisticated and complex than the "room inventory 
management" that was practiced by previous generations of hoteliers.

Computer technology has made this new sophistication and complexity possible -- so much so that many writers on the subject refer to the practice of yield management as being the same thing as using computerized yield management systems (Griffin, 1994, p. 26). Others insist that Yield Management is neither a computer system nor a set of mathematical techniques. It is a management approach (Lieberman, 1993).

\section{Problem Statement}

As there is no commonly accepted definition of "yield management" in hotels, there is a need for more information regarding the perceptions and practices of rate setters in the hotel industry. Researchers such as Jones (I992), Griffin (1994), Kimes (1989), and Orkin (1988) have all suggested that there are certain essential elements to any yield management system. This study combines their conclusions into one list of the essential elements of yield management, then tests the extent to which these elements are utilized by hotel general managers who believe that they are practicing yield management.

The purpose of this research is to survey a representative sample of hotel general managers and obtain 
information on their perceptions, understanding and utilization of yield management. The results of this study will increase our understanding of the extent to which rate setters in the hotel industry use yield management techniques.

In an attempt to clarify the meaning and industry acceptance of yield management, this study proposes that yield management in hotels consists of the following essential elements:

1. Customers must be segmented by their willingness / ability to pay. Griffin (1994) and Kimes (1989) indicate that customers must be segmented by "price elasticity" or "demand elasticity."

2. Booking patterns for each segment must be determined. Griffin (1994) refers to this as determining the "time sensitivity" for each segment while Kimes (1989) calls it a "booking pattern" and includes over booking tendencies for the segment.

3. Demand patterns for each segment must be determined. Jones (1992) and Kimes (1989) both include this item as essential to yield management.

4. Sales must be tracked and analyzed by segment. All of the aforementioned researchers include this element in their respective lists. 
5. Denials, and regrets must be tracked and analyzed by segment. Jones shows why it is essential to track what he calls "declines" and "denials" (1992).

6. Occupancy must be forecasted by segment. This item is included in Griffin's (1994) list of essential

elements, and it is implied in those of the other researchers.

7. The absolute price floor must be close to the marginal sales cost. Orkin (1988) addresses the basis behind this requirement.

8. The hotel must utilize some optimal room allocation method. This is the final objective of yield management (Griffin, 1994). The other essential elements are undertaken in preparation to accomplish this.

\section{Research Hypotheses}

This study will use the foregoing list of yield management's essential elements to test the extent to which yield management is currently practiced in hotels. The extent to which these elements are in place is the extent to which yield management is being practiced. Accordingly, this research will test the following propositions:

1. Managers who perceive that they practice yield management utilize more of the essential elements 
than managers who do not perceive that they practice yield management.

2. Managers who practice yield management segment their customers by willingness-to-pay.

3. Managers who practice yield management track booking patterns by segment.

4. Managers who practice yield management track demand patterns by segment.

5. Managers who practice yield management track sales by segment.

6. Managers who practice yield management track denials and regrets by segment.

7. Managers who practice yield management forecast occupancy by segment.

8. Managers who practice yield management fix the absolute price floor close to the marginal sales cost.

9. Managers who practice yield management utilize some optimal room allocation technique.

\section{Contribution of This Study}

This research will expand knowledge of the acceptance, understanding and use of yield management in the hotel industry. It will also put forward a practical definition of "yield management" as the term applies to the hotel 
industry. By so doing, it will help researchers, hotel managers, software developers, and educators better understand the essence of yield management as well as its practical influence in hotel room pricing in 1997.

\section{Delimitations}

This study will not investigate the effectiveness of yield management in increasing room revenue, or net profits; nor will it make a comparison of alternative methods of maximizing yield in hotels. The focus of this research is to determine the practical influence of yield management on day-to-day hotel operations.

\section{Organization of This Study}

The results of this research will be reported as follows:

$\diamond$ Chapter 1 (this chapter) presents the background and history of yield management along with a statement of the research problem.

$\diamond$ Chapter 2 is a review of prior research on yield management in the hotel industry.

$\diamond$ Chapter 3 describes the research methodology employed in this study.

$\diamond$ Chapter 4 contains the results of the study along with a statistical analysis of the data collected. A 
test of the previously described hypotheses is conducted.

$\diamond$ Chapter 5 discusses the implications of this research for the industry and for future research on yield management. 
CHAPTER 2

\section{LITERATURE REVIEW}

This chapter will cite published research to define the essential elements of a yield management system as elaborated in chapter 1. A summary conclusion will follow, showing how each of these elements fits together and why each is essential to yield management.

\section{Yield}

In the past, managers have concentrated on occupancy percentage and average daily room rate in their quest to maximize revenue. Today's yield management strategy combines these statistics and compares them to a theoretical maximum revenue or opportunity revenue.

The basic yield statistic is expressed by the equation:

\section{Yield = Actual Revenue Realized}

where maximum potential revenue equals the revenue generated by $100 \%$ occupancy at rack rate (Orkin 1988). An equivalent yield can be generated by any number of combinations of occupancy and average rate as the following table 
illustrates for a 100 room hotel with a $\$ 75$ rack rate.

Table 1

Equivalent yield combinations

\begin{tabular}{rrrrr}
\hline occupancy & $\begin{array}{c}\text { average } \\
\text { rate }\end{array}$ & $\begin{array}{c}\text { actual } \\
\text { revenue }\end{array}$ & $\begin{array}{c}\text { potential } \\
\text { revenue }\end{array}$ & yield \\
\hline $100 \%$ & $\$ 50.00$ & $\$ 5000$ & $\$ 7500$ & $67 \%$ \\
$80 \%$ & $\$ 62.50$ & $\$ 5000$ & $\$ 7500$ & $67 \%$ \\
$60 \%$ & $\$ 83.33$ & $\$ 5000$ & $\$ 7500$ & $67 \%$ \\
\hline
\end{tabular}

Kimes, among others, takes exception to the yield statistic as a useful measure of yield because the rack rate on which it is based is an arbitrary and subjective comparison. She contends that "yield for a hotel would be measured as revenue per available room" or REVPAR (Kimes, 1990, p. 189). REVPAR is the total room revenue divided by the number of available room nights. For the previously hypothesized 100 room hotel, the REVPAR for the various rate and occupancy scenarios would also be equal.

Table 2

Equivalent REVPAR combinations

\begin{tabular}{rcccc}
\hline occupancy & $\begin{array}{c}\text { average } \\
\text { rate }\end{array}$ & $\begin{array}{c}\text { room } \\
\text { revenue }\end{array}$ & $\begin{array}{c}\text { available } \\
\text { rooms }\end{array}$ & REVPAR \\
\hline $100 \%$ & $\$ 50.00$ & $\$ 5000$ & 100.00 & $\$ 50.00$ \\
$80 \%$ & $\$ 62.50$ & $\$ 5000$ & 100.00 & $\$ 50.00$ \\
$60 \%$ & $\$ 83.33$ & $\$ 5000$ & 100.00 & $\$ 50.00$ \\
\hline
\end{tabular}

These equations address only the revenue side of the profitability formula. Because fixed costs are such a large 
part of the total cost of operating a hotel, it is assumed that the marginal cost of renting an additional room is so small as to be practically insignificant. Yield management theory asserts that the hotel should sell a room for any amount that exceeds the marginal cost rather than let it remain unoccupied. If, for example, the marginal cost of renting a room is $\$ 20$, the hotel will benefit by selling the room for as little as $\$ 21$ rather than letting the room remain empty, even if the hotel's rack rate is $\$ 200$ or more. It is therefore assumed that "all combinations of rate and room sales that produce the same yield are equally desirable to the hotel" (Orkin, 1988, p. 52).

Merely selling all rooms at a low rate, however, will not maximize yield. The objective is to sell every room in the house at the highest possible rate, while at the same time, not allowing any room(s) to remain unoccupied. Such a practice, if accurately achieved, will theoretically maximize yield, total revenue, and net profits. To achieve this goal, the yield-management process includes determining policies for over booking and allocating hotel capacity to customers of different revenue generating potential through discriminatory pricing. Ideally, both of these policies should be concurrently incorporated in a hotel's reservation system.

Many yield management experts completely discount the 
contribution of non-room revenue to hotel profitability (Orkin, 1988, p. 53). As segmentation is at the heart of yield management, any hotelier will testify that different market segments have very different spending patterns once they are in the hotel. One researcher has shown that to maximize profits, a yield management system must do the following (Quain, 1992, p. 60):

$\diamond \quad$ Analyze the buying habits of each segment.

$\diamond \quad$ Calculate the contribution margin of each segment.

$\diamond \quad$ Base the sales decision (room inventory) on segment profitability not average rate.

An example will illustrate this point. Transient commercial rates are usually higher than group rates. For this reason, almost all yield management systems will prefer the commercial transient guest to the group. The group, however, will usually be a bigger user of the hotel's other revenue centers. Business travelers typically eat only breakfast in the hotel, while it is not unusual for group members to be served 3 meals per day, plus possibly a cocktail reception, etc.. It is true that the profit margins on food are much less than on rooms, but the principles of yield management demand that total profit dollars be the deciding factor. If the hotel establishes a typical spending 
pattern by segment, the results might look like those in table 3 .

Table 3

Contribution margin by segment

\begin{tabular}{lrr}
\hline $\begin{array}{l}\text { Profit } \\
\text { Center }\end{array}$ & Commercial & \multicolumn{1}{l}{ Group } \\
\hline CM Room & $\$ 82.32$ & $\$ 65.96$ \\
CM Eood & $\$ 6.65$ & $\$ 25.30$ \\
CM Beverage & $\$ 4.45$ & $\$ 12.05$ \\
Total CM & $\$ 93.52$ & $\$ 103.31$ \\
\hline * CM = Gross departmental & revenue \\
less direct variable cost.
\end{tabular}

Clearly, the group in this case will produce the greater profits, but most yield management systems would refuse the group if there was an opportunity to sell the rooms to commercial transient guests.

\section{Elasticity of Demand}

Elasticity of demand refers to the sensitivity of a given customer segment to price. For some segments, price plays a very small role in their travel decisions. Business must be conducted, the meeting must take place, etc.. While such a price-insensitive customer would prefer to pay less, high prices will not prevent him or her from traveling. Other customers may find that price will dictate the timing, mode, and even the feasibility of travel. 
Rate setters want to sell as much of their fixed capacity as possible to price-insensitive customers, and then sell whatever is left over to the rate-sensitive customer (Orkin, 1990). The yield management dilemma is to avoid selling a room to the price-sensitive guest that will later be in demand by the price-insensitive guest.

Yield management has both pricing and inventory management components. Hotels can manipulate their inventory in isolation, but most cannot change price without taking the reaction of competitors into consideration. "To fully use the potential of a yield management system, management must know the elasticity of demand for various rate classes and be able to make corresponding changes" (Kimes, 1989, p. 191).

Pricing has been shown to have a great effect on rooms sold because while at the national level demand is relatively price inelastic, at the local level (where all hotels operate) "even small differences in price can mean the difference between winning and losing business" (Relihan, 1989, p. 42).

The idea that some customer segments exhibit demand that is relatively more or less price elastic than other segments is essential to yield management. Yield management chooses among revenue opportunities: "judging whether that 
late-booking, price-inelastic demand will materialize is yield management's primary function" (Relihan, 1989, p. 43).

\section{Segmentation}

Market segmentation is at the heart of yield management. The "old" method of maximizing revenues was to segment the product into quality and rate categories. There were, and are, luxury hotels, mid-priced hotels, and economy hotels. Within each product segment there are subsegments such as suites, mini-suites, deluxe rooms, standard rooms, etc. These subsegments are further differentiated by location within the hotel, the quality of the view and so forth (Kimes, 1989).

Each of these segments and subsegments is given a rate that roughly corresponds to its perceived quality level. Within this product segmentation method, customer segmentation was important primarily as a means to identify and sell to the appropriate potential guests for each product segment.

Yield management market segmentation is fundamentally different from this traditional approach, even though both approaches coexist in most hotels. Yield management focuses not on product segmentation, but on customer segmentation. "For a yield management program to be effective, the firm must be able to segment its market into different types of customers" (Kimes 1989, p. 15). 
Customers are segmented not so much according to their demand for quality/luxury as according to the intensity of their need for the room as measured by their willingness to pay. Under this approach, two guests staying in identical rooms, on the same day, may be paying two very different rates (Orkin, 1988 ).

One common mechanism used to segment customers in yield management situations is the time of purchase. This is another yield management technique that has been taken directly from the airline experience. It is assumed that those who must have lower rates wili make their reservations early, while those who make their reservations late do so because they suddenly must travel, and consequently they will be willing to pay a higher rate. "People who make their reservations early are generally more price sensitive, they are willing to trade away some flexibility for a reduced price" (Weatherford, 1992, p. 832).

One of the yield management questions that managers must answer is: how many segments should there be? Does it really matter? Keep in mind that the objective of segmenting the market is to sell every room in the house at the highest possible rate, while at the same time keeping the rate low enough so that every room will be sold at some rate that is higher than the marginal sales cost of that room. A sealed-bid auction would represent the ideal yield 
management technique (Varian, 1966). Implicit in this objective is the need to avoid selling a room to a low-rate segment thus making it unavailable to sell to a higher-rate segment later on.

Addressing the difficulty of meeting that objective, Ladany (1996) proposed a model to determine the optimal number of market segments that a hotel should recognize, along with the optimal number of rooms to be assigned to each segment and the optimal price for each of those segments. He uses a "deterministic demand curve" approach to arrive at these optimal decisions.

Segmenting the market by itself is not yield management, and it will do nothing $\therefore$ maximize revenues or profits. Segmenting merely allows the manager to treat each segment differently. Yield management market segments are based on customer behavior, so various strategies can be used to appeal to the likely behavior of each segment in such a way as to maximize total revenue.

One such strategy is "packaging." The objective here is to create a discount package that appeals to rate-sensitive guests, but that is unappealing to non rate-sensitive guests. The reason being that the hotel doesn't want the higher-paying guest to convert his/her high-rate reservation into a low-rate package reservation. The goal of packaging is to "bundle items in the package that are of little value 
to the traditional rate-insensitive markets so that the overall cost of the package exceeds the straight room rate that they would pay" (Orkin 1990, p. 38).

\section{Booking Patterns}

Booking pattern refers to the length of time prior to arrival that guests book their reservations. The booking pattern will vary by segment. Therefore, once customers are divided into segments based on their willingness to pay, the rate setter needs to know the expected booking pattern for each segment as a preliminary step to allocating rooms among those segments. These patterns can only be determined with experience. Hotel information systems must allow the capture and reporting of these booking patterns. With this data, the hotel can create booking curves like the one in figure 1 , commonly known as "threshold" curves (Sheel, 1994).

The curve shows how the cumulative rooms booked builds as the day of arrival approaches. For the segment illustrated in figure 1, at 50 days prior to arrival there should be 60 rooms booked.

When analyzing booking patterns, the hotel manager must consider no-shows, cancellations and walk-ins. Bitran (1995, p. 428) has shown that "because of the cancellations at the tactical level and no-shows at the operational one, managers usually over book to maximize the total expected 
profit." Cancellations and no-shows generally follow a binomial distribution, and their occurrence varies by customer segment (Griffin, 1995, p.59).

\section{Figure 1}

Threshold curve

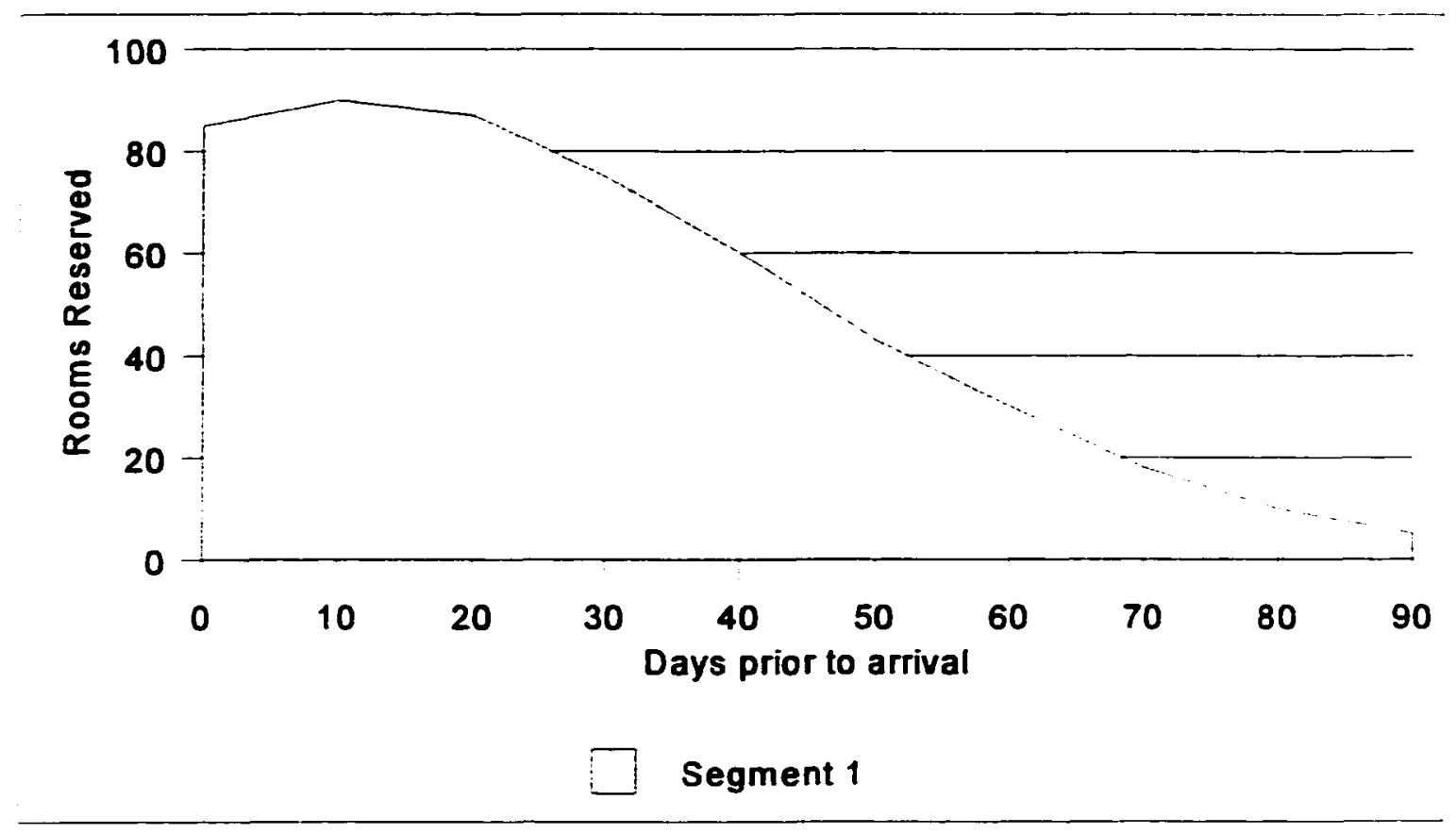

The probability of no-shows, cancellations, and walk-ins must be determined for each customer segment so that an over booking policy can be formulated to compensate for business lost to no-shows and cancellations. "The over booking policy must be integrated with the yield management program or sales will be limited to an arbitrarily low level" (Kimes 1989, p. 191). 


\section{Demand Patterns}

Demand pattern refers to the seasonal nature of demand for hotel rooms. These patterns will also vary by segment. It is commonly understood, for example, that demand from business travelers is high Monday through Thursday, while demand from leisure travelers is high on the weekends. Likewise, beach resorts enjoy high demand during the summer months while ski resorts enjoy high demand during winter months. Each customer segment will have its own, unique demand pattern (Quain, 1992).

It is often the case that there will be a correlation in demand between customer segments (Kimes, 1989). A hotel must have an understanding of the demand interaction between segments in order to allocate inventory optimally.

The demand characteristics for each market segment can be determined by experience. A hotel must have historical demand information available by market segment. This historical data is used to develop probability curves for the demand of each market segment (Kimes, 1990). From this, occupancy forecasts by segment can be generated.

\section{Sales Denials and Regrets}

Sales here refers to satisfied demand, while both denials and regrets refer to unsatisfied demand. Total demand is the sum of the two. More specifically, a "sale" is 
a room sold. A "denial" is a reservation that was attempted but not completed because of a customer decision. For example, a potential guest may call to make a reservation for a Saturday night at the weekend rate. While both the date and the rate are available, the guest decides that the rate is too high and declines to complete the reservation. A "regret" is a reservation that was attempted but not completed because of a hotel decision. If, in the previous example, the hotel had rooms available for saturday night, but chose not to sell any of them at the weekend rate, thereby refusing the potential guest, this would be a "regret."

Many hotels only track sales by market segment. It should be clear, however, that total demand by segment can only be determined by tracking sales, denials, and regrets. To track only satisfied demand is to guarantee yield stagnation from year to year. Yield maximization is based on a forecast of opportunity revenue. Denials and regrets are the only sure way to estimate the opportunity revenue (Jones, 1992).

\section{Eorecasting}

All yield management systems depend on demand forecasting, but these forecasts range from educated guesses to intricate statistical models (Relihan, 1989). Both 
econometric and time-series models are used to forecast demand, as are much less well-defined methods. The predictive power of any of the forecasting models depends on the accuracy and extent of the hotel's historical data. For that reason, it is more difficult to implement a yield management system for a new hotel than for one that has been in operation for some time (Andrew, 1990).

It is necessary to forecast both aggregate demand and demand by market segment. It is the segmentation that allows the hotel to discriminate among potential guests and maximize revenue. Forecasting is one area in which the use of computer technology is an indisputable plus. Prior to the widespread use of central reservation systems (CRS) and property management systems (PMS), it would have been very difficult to gather and retrieve reservation data by date, day of the week, special event, and market segment. All of this data must be easily accessible for any yield management system to be effective (Kimes, 1990).

Yield management systems typically use their historical data on reservations and denials and regrets to construct a demand calendar. For each future date, the calendar will estimate demand for that day by each market segment. Yield management is then simply a matter of mixing the demand from each segment in such a way as to maximize room revenue for that day. 


\section{Computer technology is also useful in converting}

historical data into forecasts. The management of a hotel can arrive at an individual forecast in any one of the following ways (Andrew, 1990):

$\diamond \quad$ Base the forecast demand on the average demand for the same date for the prior $x$ number of years.

$\diamond \quad$ Base the forecast demand on the average demand for the same chronological day of the week for the prior $x$ number of years. ("Chronological day of the week" i.e. Ist Monday of the year, 26th Friday of the year, etc.).

$\diamond \quad$ Base the forecast demand on recurring special events.

$\diamond \quad$ Use a statistical forecast model to stipulate any of the above methods.

There are several computer models to help with this last method -- some computerized yield management systems have these forecast models built in. One common predictive model is the "Box-Jenkins" model. This is a time-series model that is auto regressive in nature. It produces a moving average based on historical data in a manner similar to exponential smoothing. It has proven to be a better. 
predictor of demand than exponential smoothing, particularly for longer range forecasting (Andrew, 1990).

Another promising method to generate demand forecasts is by use of a computer simulation program. One inexpensive and fascinating program is called "Crystal Ball", and is an MS Excel add-on. This program can run a Monte Carlo - Iike simulation on a range of spreadsheet numbers. It is called from within Excel much as a function would be. On a good Pentium processor, this model can run several hundreds of thousands of simulations in a few minutes. This kind of simulation greatly increases the accuracy of the forecast (Kelliher and Atkinson, 1996).

\section{Pricing and Marginal Cost}

AIl yield management decisions ultimately relate to price. The Ladany model, among others, demonstrates that "the traditional cost-plus pricing methods used by the hotel industry to determine room rates have contributed to this phenomenon of sub-optimal sales [at prices] that do not clear the market." (Ladany, 1996, 29).

Yield management pricing strategies can be simplified as follows (Orkin, 1988):

1. In periods of relatively high demand -maximize rate. 
2. In periods of relatively high supply -maximize occupancy.

Discriminatory pricing or differential pricing is at the heart of yield management. Varian has shown that "the classic prescription for economically efficient pricing -to set price at marginal cost," is not efficient or appropriate for industries that exhibit increasing returns to scale and large fixed costs such as the hotel and airline industries (Varian, 1996). In such cases, price discrimination is both common and efficient.

There are three degrees of price discrimination (Varian, 1996):

$\diamond \quad$ 1st degree: Each unit is sold to the individual who values it most highly at the maximum price he is willing to pay (such as at an auction). This is "perfect price discrimination".

$\diamond \quad$ 2nd degree: Prices depend on the amount purchased. Volume discounts are an example.

$\diamond \quad 3 r d$ degree: Prices vary by customer type, but each individual always pays the same price. Senior citizen discounts are an example.

Hotels would like to practice lst degree price discrimination, but customers' perceptions of "fairness" are violated by such a scheme, and pursuit of 1 st degree price 
discrimination can have disastrous long-term effects on hotel profitability (Kimes, 1994). In practice, hotels use 3 degree price discrimination in their yield management efforts (Varian, 1996).

Orkin (1990) contends that, while common, 2nd degree price discrimination (volume discounts) is antithetical to yield management because it disregards ability to pay. To offer volume discounts to price-insensitive corporate customers is foolish in a yield management context. The airlines, for example, charge the highest fares to their best customers.

Operating a hotel is a very expensive enterprise. The cost of the land, the building, the furnishings, as well as the utilities and most of the staff. are incurred and fixed regardless of the hotel's occupancy. "Marginal sales cost" refers to those costs incurred in serving just one more guest. These costs are basically limited to the cost of cleaning and supplying the room and are about $\$ 7.00$ to $\$ 20.00$ for most hotels (Orkin, 1990).

If a hotel sold all of its rooms for a price close to its marginal sales cost, it would fail in short order as the great majority of its total costs are fixed. On the other hand, it makes perfect sense for a hotel to sell a $\$ 200$ room for $\$ 50$ if the room would otherwise be unoccupied. "Any discount [rate] right down to one cent above the [marginal 
sales] cost, will increase profits if the alternative is to have [empty rooms]" (Orkin, 1990).

In industries where capacity is fixed, marginal

production cost is high, and marginal sales cost is low, "the basic requirement that efficiency imposes is [that]... marginal willingness to pay must equal marginal cost" (Varian, 1996). That is: revenue will be maximized when the marginal room is sold to a guest at the highest possible rate that exceeds the marginal sales cost.

\section{Optimal Allocation \\ of Room Inventory}

While there are various techniques that can be used to determine the optimal allocation of room inventory, the focus of each is to keep each room available for the guest that is likely to pay the most for it, while at the same time selling every room for some rate above the marginal sales cost. This task is complicated by the fact that "one of the key characteristics of the yield management problem is that it must be solved repeatedly. Because of this, any solution method must be fast, fairly accurate, and not too expensive" (Kimes, 1990, p. 191).

There are basically four approaches to the allocation problem (Griffin 1994, Kimes 1990, Relihan, 1989). The first, and probably common is threshold pricing. Using this 
method, the hotel will use its segmented demand forecast to determine optimal mix of guests for a given day. For example a 100 room hotel may decide that for a given date the highest-rate segment will demand 30 rooms, the next highest segment will demand 50 rooms, the next highest segment will demand 70 rooms, and the lowest-rate segment will demand 90 rooms. Since the lowest-rate segment tends to make their reservations first, the objective is to avoid selling rooms to them that could be sold at a later date to a segment that pays a higher rate.

In this example, the hotel would allocate their 100 rooms as in table 4 .

Table 4

Sample Segment Allocation

\begin{tabular}{lrr}
\hline Group & Demand & Allocation \\
\hline Group 1 & 30 & 30 \\
Group 2 & 50 & 50 \\
Group 3 & 70 & 20 \\
Group 4 & 90 & 0 \\
\hline
\end{tabular}

The hotel would then take this allocation and combine it with the previously determined booking patterns to produce the threshold curve shown in figure 2(Sheel, 1994). For any day prior to arrival, the hotel would accept reservations from any segment whose cumulative booked reservations are less than the point on the curve for that 
day. The line for the highest-rate group is flat at 100 because reservations for this group should never be turned down. The line for the lowest-rate group is flat at 0 , because in this example no reservations will be accepted from this group. "Within these thresholds are where tactical price decisions are made" (Shaw, 1992, p. 36).

Figure 2

Allocation by Threshold Curve

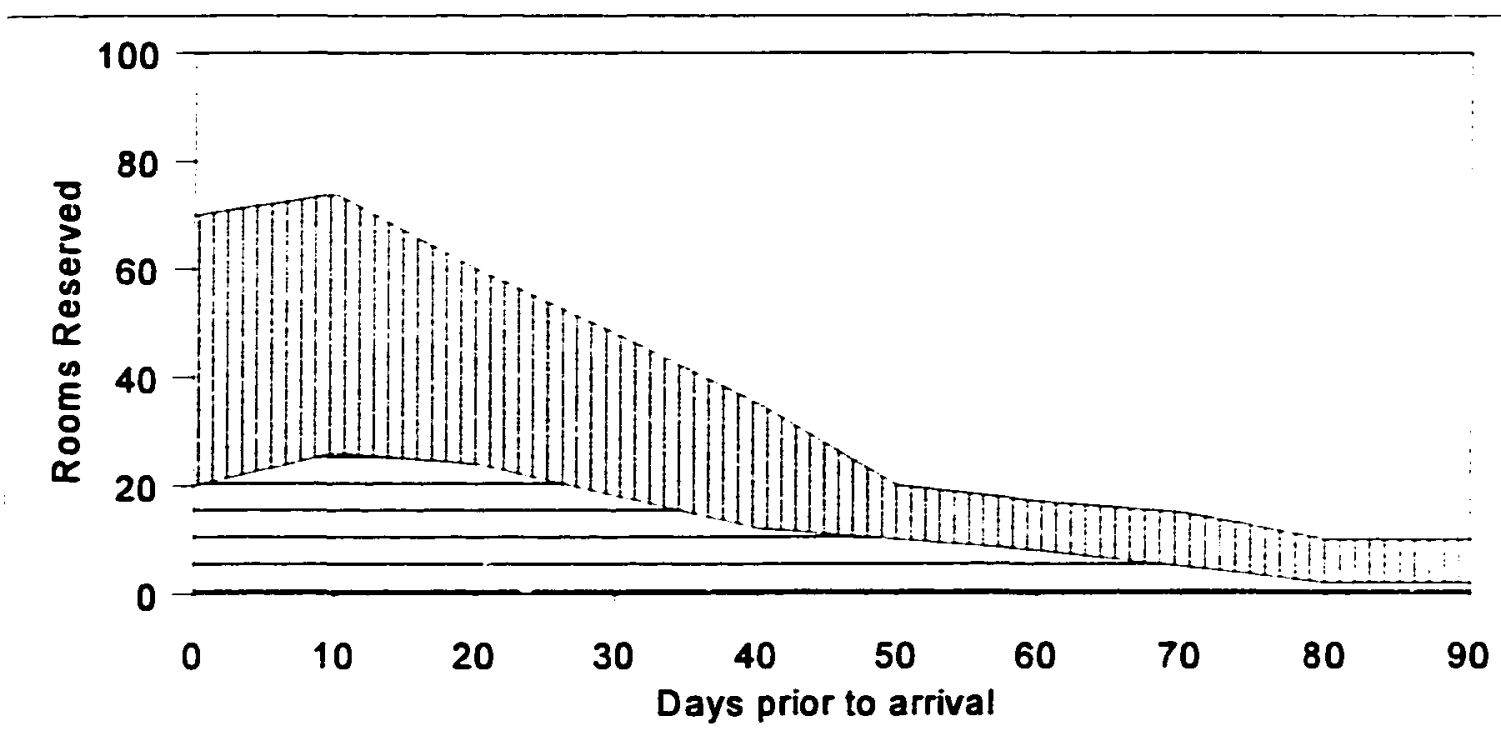

- Group 1 III Group $2 \equiv$ Group 3 Group 4

A technique that is commonly used in the airline industry is the "expected marginal seat revenue" model or EMSR (Belobaba, 1989). This model requires more computer power and sophistication than the threshold method, but it produces more truly optimal results. It requires estimates of the mean and standard deviation of requests by rate 
class. It then closes down a low rate class when the certain revenue from selling another low fare seat is exceeded by the expected revenue from saving the seat for a potential high-rate guest (Belobaba, 1989).

The developer of this model has concluded that, in terms of airline use: "The greatest challenge in the development and testing of the [system] was to provide the managements of the airlines involved with proof of the revenue benefits of the system. This task was complicated by the inherent difficulties of measuring impact of any seat inventory control policies, given the numerous variables that can contribute to the demand and revenue on a particular flight. Furthermore, the notion of maximizing expected revenues seemed difficult for management to comprehend, particularly when shown results for individual flights that were clearly not optimal. The probabilistic nature of demand and the mathematical formulations can be counterintuitive to the results oriented airline manager" (Belobaba, 1989, p. 197).

A third approach is to determine optimal allocation by use of mathematical programming si:h as linear programming, non linear programming and probabilistic linear programming. There are many proposed models for accomplishing this (Relihan, 1989; Griffin, 1994; Andrew, 1990), but at the 
present "time and required computing power limit feasibility" (Kimes, 1990, p. 191).

The last approach is to utilize some kind of "expert system" to make booking decisions. These systems are "rule-based" computer systems that can incorporate both qualitative and quantitative rules (Griffin, 1995). Many computerized hotel yield management systems use expert system technology, although it is difficult to discover exactly how these systems operate due to the proprietary nature of the software product.

In the near future, it is likely that the yield management problem will be increasingly solved by neural networks, which are "truly intelligent computers -- capable not only of dealing with unforeseen situations, but also of synthesizing knowledge from random data with little or no help" (Relihan, 1989, p. 44). In the meartime, yield management implementation can present a complex challenge for hotel staffs that are notoriously underpaid and subject to high turnover.

\section{Summary}

There are eight elements of yield management in hotels. To maximize room revenue, a hotel will use all of them. Ideally, the hotel is ready to allocate its room inventory optimally only when the prerequisites have been 
accomplished. The hotel must have knowledge of the demand elasticity for various groups of guests. It must then segment its guests by their relative willingness to pay. Once these segments are identified, the hotel must track its sales, denials and regrets to determine the booking patterns and demand patterns for each segment. Then an occupancy forecast by segment can be made. The hotel must also have knowledge of its marginal sales cost in order to set an absolute price floor. 


\section{please note}

\section{Pago(s) miasing in number only, wxt follows. Findod as recoived.}

\section{UMI}

Reproduced with permission of the copyright owner. Further reproduction prohibited without permission. 
CHAPTER 3

METHODOLOGY

The purpose of this study was to obtain information from hotel general managers regarding their perceptions, understanding and utilization of yield management. It has sought to answer the fundamental question: Do the perceptions of general managers regarding their use of yield management techniques agree with their actual practices?

The purpose of this chapter is to discuss how the study was conducted, the procedures used to gather the research data, and the methods used to analyze the data. This chapter will also discuss the design of the questionnaire, and the survey administration.

Questionnaire Design

The population of interest for this study is general managers of hotels and motels with 100 or more rooms in the United states. Previous research has shown that this population has a great deal of autonomy in setting room rates for their individual hotels (Gu \& Caneen, 1996). General managers of hotels with fewer than 100 rooms were removed from consideration prior to selection because 
research has shown that managers of such hotels and motels do not have the sophistication to employ yield management (Gamble, 1990).

A sample of 600 general managers was randomly selected from the 1994 edition of "Who's who in the Lodging Industry," published by the American Hotel \& Motel Association. It was felt that the sample gathered from this source was too heavily weighted towards small "mom and pop" operations. Therefore, an additional 400 general managers were selected randomly from the Spring 1995 edition of the "Hotel and Travel Index."

The design of the survey questionnaire was based on the need to gather information about the specific operational procedures employed by rate setters in the hospitality industry. The questionnaire incorporated the principles of survey design as described in "Marketing Research in a Marketing Environment," by Dillon, Madden and Eirtile (Dillon, et. al., 1994).

Most of the questions relevant to this research required the respondent to choose an answer based on the 5point Likert scale. This simplified the survey, allowing it to be completed quickly by the respondents. This strategy was used in the hope of maximizing the response rate. A sample questionnaire is included in appendix $A$. Some of the 
survey questions were designed for a different study and will not be used for this thesis.

Questions 1 - 5 were designed to categorize the respondent hotel property by size, chain affiliation, and market segment.

Question 6 asked for the general managers' perceptions of the strength of demand in his/her market.

Questions $7-12$ were designed to ascertain certain

basic facts about the hotels' rate structure.

Questions 13 and 14 were designed to test the respondent's awareness of his/her marginal sales cost and its relationship to a price "floor" as it relates to yield management.

Questions 15 - 17 were designed to categorize the respondent by experience and education. Questions 23 - 25 were designed to ascertain the practices of the respondent relative to customer segmentation.

Questions 26 - 35 were designed to test the extent to which the respondent utilizes the essential elements of yield management as proposed in chapter one of this research.

Question 30 is of particular importance because it was used to divide the respondents into two groups for hypothesis testing. The two groups are those who perceive 
that they use yield management techniques extensively, and those who do not perceive that they use them extensively.

\section{Survey Administration and Sample selection}

It was determined that a minimum sample size of 120 was necessary for representativeness at a $95 \%$ confidence level and a precision of $\pm 10 \%$. This calculation was based on the expected population mean of 2.5 and variance of 2 on the 5 point scale used extensively in the survey. Previous experience suggested the probability of a $22 \%$ response rate (Gu \& Caneen, 1996). It was necessary, therefore, to solicit responses from a random sample of at least 545 (Dillon, et. a1., 1994).

To allow for a lower response rate or the ability to reduce the sample size to maintain representativeness, a total of 1000 survey questionnaires were mailed.

\section{Data Collection}

The survey questionnaire, along with a cover letter (appendix $A$ ) and a postage-paid return envelope were sent by U.S. bulk mail. One thousand pieces were sent. Eighty four completed surveys were returned for a response rate of approximately $8 \%$. In order to attain the minimum required sample size, non-respondents were randomly surveyed by 
telephone. Two hundred seventy four (274) telephone calls were made, and 42 surveys were completed for a response rate of 15.3\%. A total of 126 completed surveys were gathered. The following charts show a breakdown of respondents by market area, size of the hotel, type of management organization, service level, market segment, average rate, occupancy, and the education and experience of the general manager. In each chart, the column labeled "percent" represents the percentage of all respondents, while the column labeled "valid percent" represents the percentage of respondents who answered the question. "Cumulative percent" is a running total of the "valid percent" column. 
Table 5

Response Frequency by State

\begin{tabular}{|c|c|c|c|c|}
\hline state & Erequency & Percent & $\begin{array}{l}\text { Valid } \\
\text { Percent }\end{array}$ & $\begin{array}{c}\text { Cumulative } \\
\text { Percent }\end{array}$ \\
\hline $\mathrm{AL}$ & 1 & 0.80 & 0.90 & 0.90 \\
\hline $\mathrm{AZ}$ & 3 & 2.40 & 2.60 & 3.50 \\
\hline $\mathrm{CA}$ & 15 & 11.90 & 13.20 & 16.70 \\
\hline $\mathrm{CO}$ & 7 & 5.60 & 6.10 & 22.80 \\
\hline DC & 1 & 0.80 & 0.90 & 23.70 \\
\hline$D E$ & 1 & 0.80 & 0.90 & 24.60 \\
\hline FL & 6 & 4.80 & 5.30 & 29.80 \\
\hline GA & 2 & 1.60 & 1.80 & 31.60 \\
\hline HI & 1 & 0.80 & 0.90 & 32.50 \\
\hline ID & 1 & 0.80 & 0.90 & 33.30 \\
\hline IL & 2 & 1.60 & 1.80 & 35.10 \\
\hline IN & 1 & 0.80 & 0.90 & 36.00 \\
\hline KS & 3 & 2.40 & 2.60 & 38.60 \\
\hline KY & 1 & 0.80 & 0.90 & 39.50 \\
\hline MA & 2 & 1.60 & 1.80 & 41.20 \\
\hline MD & 1 & 0.80 & 0.90 & 42.10 \\
\hline MI & 2 & 1.60 & 1.80 & 43.90 \\
\hline MN & 3 & 2.40 & 2.60 & 46.50 \\
\hline MO & 8 & 6.30 & 7.00 & 53.50 \\
\hline MS & 2 & 1.60 & 1.80 & 55.30 \\
\hline MT & 2 & 1.60 & 1.80 & 57.00 \\
\hline NC & 6 & 4.80 & 5.30 & 62.30 \\
\hline ND & 1 & 0.80 & 0.90 & 63.20 \\
\hline NH & 2 & 1.60 & 1.80 & 64.90 \\
\hline NM & 2 & 1.60 & 1.80 & 66.70 \\
\hline NY & 6 & 4.80 & 5.30 & 71.90 \\
\hline
\end{tabular}


Table 5

Response Erequency by State

\begin{tabular}{|c|c|c|c|c|}
\hline State & Erequency & Percent & $\begin{array}{l}\text { Valid } \\
\text { Percent }\end{array}$ & $\begin{array}{c}\text { Cumulative } \\
\text { Percent }\end{array}$ \\
\hline $\mathrm{OH}$ & 2 & 1.60 & 1.80 & 73.70 \\
\hline OK & 2 & 1.60 & 1.80 & 75.40 \\
\hline OR & 1 & 0.80 & 0.90 & 76.30 \\
\hline $\mathrm{PA}$ & 6 & 4.80 & 5.30 & 81.60 \\
\hline RI & 1 & 0.80 & 0.90 & 82.50 \\
\hline SC & 1 & 0.80 & 0.90 & 83.30 \\
\hline$S D$ & 1 & 0.80 & 0.90 & 84.20 \\
\hline $\mathrm{TN}$ & 1 & 0.80 & 0.90 & 85.10 \\
\hline $\mathrm{TX}$ & 8 & 6.30 & 7.00 & 92.10 \\
\hline UT & 1 & 0.80 & 0.90 & 93.00 \\
\hline VA & 3 & 2.40 & 2.60 & 95.60 \\
\hline VT & 1 & 0.80 & 0.90 & 96.50 \\
\hline WA & 1 & 0.80 & 0.90 & 97.40 \\
\hline$W I$ & 2 & 1.60 & 1.80 & 99.10 \\
\hline WY & 1 & 0.80 & 0.90 & 100.00 \\
\hline UKNOWN * & 12 & 9.50 & - & - \\
\hline Total & 126 & 100.00 & 100.00 & \\
\hline
\end{tabular}

* Responses received without postmark 
Table 6

Response Erequency by Size of Hotel

\begin{tabular}{lrrrr}
\hline No. Of Rooms & Frequency & Percent & $\begin{array}{c}\text { Valid } \\
\text { Percent }\end{array}$ & $\begin{array}{c}\text { Cumulative } \\
\text { Percent }\end{array}$ \\
\hline Less Than 200 & 55 & 43.70 & 48.20 & 48.20 \\
$200-399$ & 44 & 34.90 & 38.60 & 86.80 \\
$400-599$ & 8 & 6.30 & 7.00 & 93.90 \\
600 or more & 7 & 5.60 & 6.10 & 100.00 \\
no response & 12 & 9.50 & - & - \\
Total & 126 & 100.00 & 100.00 & \\
\hline
\end{tabular}

Table 7

Response Erequency by Type of Organization

\begin{tabular}{lrrrr}
\hline Type & Erequency & Percent & $\begin{array}{c}\text { Valid } \\
\text { Percent }\end{array}$ & $\begin{array}{c}\text { Cumulative } \\
\text { Percent }\end{array}$ \\
\hline Major chain & 42 & 33.30 & 33.60 & 33.60 \\
Management Co. & 35 & 27.80 & 28.00 & 61.60 \\
Independent & 48 & 38.10 & 38.40 & 100.00 \\
No Response & 1 & 0.80 & - & - \\
Total & 126 & 100.00 & 100.00 & \\
\hline
\end{tabular}

Reproduced with permission of the copyright owner. Further reproduction prohibited without permission. 
Table 8

Response Rate by Service Level

\begin{tabular}{lrrrr}
\hline Service Level & Frequency & Percent & $\begin{array}{c}\text { Valid } \\
\text { Percent }\end{array}$ & $\begin{array}{c}\text { Cumulative } \\
\text { Percent }\end{array}$ \\
\hline Eull Service & 94 & 74.60 & 74.60 & 74.60 \\
Limited Service & 25 & 19.80 & 19.80 & 94.40 \\
All Suite & 7 & 5.60 & 5.60 & 100.00 \\
No Response & - & - & - & \\
Total & 126 & 100.00 & 100.00 & \\
\hline
\end{tabular}

Table 9

Response Rate by Primary Market

\begin{tabular}{lrrrr}
\hline $\begin{array}{l}\text { Primary } \\
\text { Market }\end{array}$ & Erequency & Percent & $\begin{array}{c}\text { Valid } \\
\text { Percent }\end{array}$ & $\begin{array}{c}\text { Cumuiative } \\
\text { Percent }\end{array}$ \\
\hline Commercial & 88 & 69.80 & 69.80 & 69.80 \\
Convention & 12 & 9.50 & 9.50 & 79.40 \\
Resort & 24 & 19.00 & 19.00 & 98.40 \\
Extended Stay & 2 & 1.60 & 1.60 & 100.00 \\
No Response & - & - & - & \\
Total & 126 & 100.00 & 100.00 & \\
\hline
\end{tabular}


Table 10

Response Rate by Average Daily Room Rate

\begin{tabular}{|c|c|c|c|c|}
\hline Average Rate & Erequency & Percent & $\begin{array}{l}\text { Valid } \\
\text { Percent }\end{array}$ & $\begin{array}{c}\text { Cumulative } \\
\text { Percent }\end{array}$ \\
\hline less than $\$ 50$ & 14 & 11.10 & 11.50 & 11.50 \\
\hline$\$ 51-\$ 75$ & 43 & 34.10 & 35.20 & 46.70 \\
\hline$\$ 76-\$ 100$ & 35 & 27.80 & 28.70 & 75.40 \\
\hline$\$ 101-\$ 125$ & 13 & 10.30 & 10.70 & 86.10 \\
\hline$\$ 126-\$ 150$ & 9 & 7.10 & 7.40 & 93.40 \\
\hline$\$ 151-\$ 175$ & 4 & 3.20 & 3.30 & 96.70 \\
\hline$\$ 176-\$ 200$ & 1 & 0.80 & 0.80 & 97.50 \\
\hline$\$ 201-\$ 225$ & - & - & - & 97.50 \\
\hline$\$ 226-\$ 250$ & - & - & - & 97.50 \\
\hline$\$ 251-\$ 275$ & - & - & - & 97.50 \\
\hline$\$ 276-\$ 300$ & - & - & - & 97.50 \\
\hline More than $\$ 300$ & 3 & 2.40 & 2.50 & 100.00 \\
\hline No Response & 4 & 3.20 & - & - \\
\hline Total & 126 & 100.00 & 100.00 & \\
\hline
\end{tabular}


Table 11

Response Rate by Occupancy

\begin{tabular}{lrrrr}
\hline $\begin{array}{l}\text { Hotel } \\
\text { Occupancy }\end{array}$ & Frequency & Percent & $\begin{array}{c}\text { Valid } \\
\text { Percent }\end{array}$ & $\begin{array}{c}\text { Cumulative } \\
\text { Percent }\end{array}$ \\
\hline $65 \%$ or less & 34 & 27.00 & 32.40 & 32.40 \\
$66 \%-70 \%$ & 22 & 17.50 & 21.00 & 53.30 \\
$71 \%-75 \%$ & 16 & 12.70 & 15.20 & 68.60 \\
$76 \%-80 \%$ & 15 & 11.90 & 14.30 & 82.90 \\
More than $80 \%$ & 18 & 14.30 & 17.10 & 100.00 \\
No Response & 21 & 16.70 & & \\
Total & 126 & 100.00 & 100.00 & \\
\hline
\end{tabular}

Table 12

Response Rate by GM Experience

\begin{tabular}{lrrrr}
\hline Years & Erequency & Percent & $\begin{array}{c}\text { Valid } \\
\text { Percent }\end{array}$ & $\begin{array}{c}\text { Cumulative } \\
\text { Percent }\end{array}$ \\
\hline Less than 5 & 64 & 50.80 & 51.60 & 51.60 \\
$6-10$ & 33 & 26.20 & 26.60 & 78.20 \\
$11-15$ & 14 & 11.10 & 11.30 & 89.50 \\
$16-20$ & 10 & 7.90 & 8.10 & 97.60 \\
More than 20 & 3 & 2.40 & 2.40 & 100.00 \\
No Response & 2 & 1.60 & - & - \\
Total & 126 & 100.00 & 100.00 & - \\
\hline
\end{tabular}


Table 13

Response Rate by GM Education

\begin{tabular}{lrrrr}
\hline Highest Level & Frequency & Percent & $\begin{array}{c}\text { Valid } \\
\text { Percent }\end{array}$ & $\begin{array}{c}\text { Cumulative } \\
\text { Percent }\end{array}$ \\
\hline High School & 7 & 5.60 & 5.60 & 5.60 \\
Some College & 33 & 26.20 & 26.20 & 31.80 \\
BS Hospitality & 37 & 29.40 & 29.60 & 61.40 \\
BS Other & 41 & 32.50 & 32.80 & 94.20 \\
Advanced degree & 7 & 5.60 & 5.60 & 100.00 \\
No Response & 1 & 0.80 & - & - \\
Total & 126 & 100.00 & 100.00 & - \\
\hline
\end{tabular}


Data Analysis

A statistical software package, SPSS 6.0 was used for data input and analysis. Representativeness was analyzed using three factors: hotel size, occupancy, and average rate. Data gathered from the sample was compared to data supplied by Pannell, Kerr, and Forster (PKF Consulting, 1995). The chi-square test was used to compare the samples. Results are reported in chapter 5 .

Hypothesis Testing

The data from the completed surveys was used to test the nine hypotheses listed in chapter 1 . This section will list each proposition as stated in chapter one, restate it as a null and alternative hypothesis, and describe the statistical tool used to test each hypothesis.

Proposition 1: Managers who perceive that they use yield management techniques extensively utilize more of the essential elements of YM than managers who do not have this perception.

$H 1_{0}$ : The number of the essential elements of yield management that managers practice is independent of their perception of their yield management behavior. $\mathrm{H} I_{\mathrm{A}}$ : The number of the essential elements of yield management that managers practice is related to their perception of their yield management behavior. 
Proposition 2: Managers who tend to practice yield management extensively are more likely to segment their customers by willingness to pay. H2o: The degree to which managers segment their customers by willingness to pay is independent of their perception of their yield management behavior. $\mathrm{H} 2_{\mathrm{A}}$ : The degree to which managers segment their customers by willingness to pay is related to their perception of their yield management behavior.

Proposition 3: Managers who tend to practice yield management extensively are more likely to track booking patterns by segment.

H30: The degree to which managers track booking patterns by segment is independent of their perception of their yield management behavior.

$\mathrm{H} 3_{\mathrm{A}}$ : The degree to which managers track booking patterns by segment is related to their perception of their yield management behavior.

Proposition 4: Managers who tend to practice yield management extensively are more likely to track demand patterns by segment. H40: The degree to which managers track demand patterns by segment is independent of their perception of their yield management behavior. 
$\mathrm{H} 4_{\mathrm{A}}$ : The degree to which managers track demand patterns by segment is related to their perception of their yield management behavior.

Proposition 5: Managers who tend to practice yield management extensively are more likely to track sales by segment.

H5: The degree to which managers track sales by segment is independent of their perception of their yield management behavior.

$H 5_{\mathrm{A}}$ : The degree to which managers track sales by segment is related to their perception of their yield management behavior.

Proposition 6: Managers who tend to practice yield management extensively are more likely to track denials and regrets by segment.

H6o: The degree to which managers track denials and regrets by segment is independent of their perception of their yield management behavior.

$H 6_{A}$ : The degree to which managers track denials and regrets by segment is related to their perception of their yield management behavior.

Proposition 7: Managers who tend to practice yield management extensively are more likely to forecast occupancy by segment. 
H7o: The degree to which managers forecast occupancy by segment is independent of their perception of their yield management behavior.

$\mathrm{H} 7_{\mathrm{A}}$ : The degree to which managers forecast occupancy by segment is related to their perception of their yield management behavior.

Proposition 8: Managers who tend to practice yield management extensively are likely to fix the absolute price floor closer to the marginal sales cost. H8, The degree to which managers fix the absolute price floor close to the marginal sales cost is independent of their perception of their yield management behavior. H8: The degree to which managers fix the absolute price floor close to the marginal sales cost is related to their perception of their yield management behavior.

Proposition 9: Managers who tend to practice yield management extensively are more likely to utilize some optimal room allocation technique. H9o: The degree to which managers utilize some optimal room allocation technique is independent of their perception of their yield management behavior.

$\mathrm{H} 9_{\mathrm{A}}$ : The degree to which managers utilize some optimal room allocation technique is related to their perception of their yield management behavior. 
For hypotheses 1 through 7 and 9, the chi-square test was conducted to test the significance of the relationships involved. In addition, the Pearson's $\mathrm{R}$ statistic was calculated to determine the strength of the linear relationship. As the Pearson's $R$ approaches 1.0, the strength of the linear relationship increases.

Hypothesis 8 was tested using a one-tailed, independent-samples $t$ test to determine if the mean ratio of marginal sales cost to price floor was greater for YM practitioners than for the other group.

\section{Summary}

The survey instrument was designed to collect data to test the above hypotheses about the nature, acceptance and use of yield management. Research data was collected from a randomly selected sample of hotel general managers. The results of the hypothesis tests are contained in chapter 4. The level of significance for hypothesis testing was set at 5 옹. 


\section{CHAPTER 4}

SURVEY DATA

The heart of this research is based on data that was gathered from respondents in answer to survey questions 13 , 14, 23, 25 and 26 through 35. The answers to questions 13 and 14 are dollar amounts supplied by the respondent. From the answers to these questions a ratio of marginal sales cost to price floor was calculated. The larger the number, the closer the hotel's price floor is to its marginal sales cost.

The sample data revealed that the average marginal sales cost among sample hotels was $\$ 23.85$. This means that it cost the hotel, on average, $\$ 23.85$ more to rent an additional room than to leave it empty. By contrast, the average price floor was $\$ 65.16$. This is the absolute minimum price, on average, for which the hotel will sell a room. Responses to these questions are summarized as ratios in table 14 .

Question 23 asked the respondent to rank each of 5 common methods for segmenting customers. A ranking of 1 indicates highest importance, while a rank of 5 indicates 
least importance. Ranking frequencies for each option are summarized in tables 15 through 19.

Table 14

Responses to Questions \#13 and \#14 Ratio of Marginal Sales Cost to Price Floor

\begin{tabular}{lrrrr}
\hline Ratio & Erequency & Percent & $\begin{array}{r}\text { Valid } \\
\text { Percent }\end{array}$ & $\begin{array}{c}\text { Cumulative } \\
\text { Percent }\end{array}$ \\
\hline .20 or less & 6 & 4.80 & 6.20 & 6.20 \\
$.21-.40$ & 60 & 47.60 & 61.90 & 68.00 \\
$.41-.60$ & 24 & 19.00 & 24.70 & 92.80 \\
$.61-.80$ & 7 & 5.60 & 7.20 & 100.00 \\
$.81-1.00$ & 0 & 0.00 & 0.00 & 100.00 \\
No Response & 29 & 23.00 & - & - \\
Total & 126 & 100.00 & 100.00 & - \\
*Mean Marginal Cost of Sales 23.85 & Std. Dev. & 18.64 \\
*Mean Price Floor & & 65.16 & Std. Dev. 42.31
\end{tabular}

Table 15

Responses to Question \#23, Option 1

Rank the following in order of their importance in segmenting your customers. Purpose of the visit.

\begin{tabular}{lrrrr}
\hline Ranking & Erequency & Percent & $\begin{array}{c}\text { Valid } \\
\text { Percent }\end{array}$ & $\begin{array}{c}\text { Cumulative } \\
\text { Percent }\end{array}$ \\
\hline Ranked \#1 & 46 & 36.50 & 39.00 & 39.00 \\
Ranked \#2 & 32 & 25.40 & 27.10 & 66.10 \\
Ranked \#3 & 21 & 16.70 & 17.80 & 83.90 \\
Ranked \#4 & 16 & 12.70 & 13.60 & 97.50 \\
Ranked \#5 & 3 & 2.40 & 2.50 & 100.00 \\
No Response & 8 & 6.30 & - & - \\
Total & 126 & 100.00 & 100.00 & - \\
\hline
\end{tabular}


Table 16

Responses to Question \#23, Option 2

Rank the following in order of their importance in

segmenting your customers. Length of time prior to arrival that reservation is made.

\begin{tabular}{lrrrr}
\hline Ranking & Erequency & Percent & $\begin{array}{c}\text { Valid } \\
\text { Percent }\end{array}$ & $\begin{array}{c}\text { Cumulative } \\
\text { Percent }\end{array}$ \\
\hline Ranked \#1 & 10 & 7.90 & 8.90 & 8.90 \\
Ranked \#2 & 17 & 13.50 & 15.20 & 24.10 \\
Ranked \#3 & 32 & 25.40 & 28.60 & 52.70 \\
Ranked \#4 & 44 & 34.90 & 39.30 & 92.00 \\
Ranked \#5 & 9 & 7.10 & 8.00 & 100.00 \\
No Response & 14 & 11.10 & - & - \\
Total & 126 & 100.00 & 100.00 & - \\
\hline
\end{tabular}

Table 17

Responses to Question \#23, Option 3

Rank the following in order of their importance in

segmenting your customers. Type of accommodations typically required.

\begin{tabular}{lrrrr}
\hline Ranking & Erequency & Percent & $\begin{array}{c}\text { Valid } \\
\text { Percent }\end{array}$ & $\begin{array}{c}\text { Cumulative } \\
\text { Percent }\end{array}$ \\
\hline Ranked \#1 & 25 & 19.80 & 22.10 & 22.10 \\
Ranked \#2 & 40 & 31.70 & 35.40 & 57.50 \\
Ranked \#3 & 26 & 20.60 & 23.00 & 80.50 \\
Ranked \#4 & 16 & 12.70 & 14.20 & 94.70 \\
Ranked \#5 & 6 & 4.80 & 5.30 & 100.00 \\
No Response & 13 & 10.30 & - & - \\
Total & 126 & 100.00 & 100.00 & - \\
\hline
\end{tabular}


Table 18

Responses to Question \#23, Option 4

Rank the following in order of their importance in segmenting your customers. Willingness / ability to pay.

\begin{tabular}{lrrrr}
\hline Ranking & Erequency & Percent & $\begin{array}{c}\text { Valid } \\
\text { Percent }\end{array}$ & $\begin{array}{c}\text { Cumulative } \\
\text { Percent }\end{array}$ \\
\hline Ranked \#1 & 35 & 27.80 & 30.70 & 30.70 \\
Ranked \#2 & 18 & 14.30 & 15.80 & 46.50 \\
Ranked \#3 & 26 & 20.60 & 22.80 & 69.30 \\
Ranked \#4 & 29 & 23.00 & 25.40 & 94.70 \\
Ranked \#5 & 6 & 4.80 & 5.30 & 100.00 \\
No Response & 12 & 9.50 & - & - \\
Total & 126 & 100.00 & 100.00 & - \\
\hline
\end{tabular}

Table 19

Responses to Question \#23, Option 5

Rank the following in order of their importance in segmenting your customers. Other.

\begin{tabular}{lrrrr}
\hline Ranking & Frequency & Percent & $\begin{array}{c}\text { Valid } \\
\text { Percent }\end{array}$ & $\begin{array}{c}\text { Cumulative } \\
\text { Percent }\end{array}$ \\
\hline Ranked \#1 & 12 & 9.50 & 27.90 & 27.90 \\
Ranked \#2 & 1 & 0.80 & 2.30 & 30.20 \\
Ranked \#3 & 4 & 3.20 & 9.30 & 39.50 \\
Ranked \#4 & 2 & 1.60 & 4.70 & 44.20 \\
Ranked \#5 & 24 & 19.00 & 55.80 & 100.00 \\
No Response & 83 & 65.90 & - & - \\
Total & 126 & 100.00 & 100.00 & - \\
\hline
\end{tabular}

Reproduced with permission of the copyright owner. Further reproduction prohibited without permission. 
Question 25 asked the respondent to make one choice among 6 alternatives methods of allocating the available rooms among customer segments. In his comparison of allocation methods, Baker (1994) concluded that only allocation methods based on one of several mathematical models could be considered optimal. Sheel (1994) argued convincingly that allocating rooms by threshold curve, while not a mathematical model, achieves close to optimal results. For the purposes of analyzing question 25, the third option (threshold curve) and the fourth option (mathematic formula) are considered optimal allocation methods. The others are not. Responses are summarized in table 20. Questions 26 through 35 were posed in terms of the degree of the respondent's agreement as measured by the 5point Likert scale. Responses to these questions fall on a continuum of agreement with 1 = "strongly disagree" and $5=$ "strongly agree." The answers are summarized in tables 21 through 30 . 
Table 20

Responses to question \#25

How do you allocate the rooms available for sale to each segment?

\begin{tabular}{lrrrr}
\hline Method & Erequency & Percent & $\begin{array}{c}\text { Valid } \\
\text { Percent }\end{array}$ & $\begin{array}{c}\text { Cumulative } \\
\text { Percent }\end{array}$ \\
\hline $\begin{array}{l}\text { First Come, first } \\
\text { served }\end{array}$ & 14 & 11.10 & 15.70 & 15.70 \\
Eixed allocation & 24 & 19.00 & 27.00 & 42.70 \\
Threshold curve & 25 & 19.80 & 28.10 & 70.80 \\
Mathematic & 9 & 7.10 & 10.10 & 80.90 \\
formula & 10 & 7.90 & 11.20 & 92.10 \\
Intuitive & 7 & 5.60 & 7.90 & 100.00 \\
Other & 37 & 29.40 & - & - \\
No Response & 126 & 100.00 & 100.00 & - \\
Total & & &
\end{tabular}

Table 21

Responses to Question \#26

As G.M., I have complete autonomy in setting room rates.

\begin{tabular}{lrrrr}
\hline Answer & Erequency & Percent & $\begin{array}{c}\text { Valid } \\
\text { Percent }\end{array}$ & $\begin{array}{c}\text { Cumulative } \\
\text { Percent }\end{array}$ \\
\hline Strongly Disagree & 5 & 4.00 & 4.00 & 4.00 \\
Disagree & 14 & 11.10 & 11.20 & 15.20 \\
Neutral & 23 & 18.30 & 18.40 & 33.60 \\
Agree & 41 & 32.50 & 32.80 & 66.40 \\
Strongly Agree & 42 & 33.30 & 33.60 & 100.00 \\
No Response & 1 & 0.80 & - & - \\
Total & 126 & 100.00 & 100.00 & - \\
\hline
\end{tabular}

Reproduced with permission of the copyright owner. Further reproduction prohibited without permission. 
Table 22

Responses to Question \#27

I allow the desk staff and reservations staff to use their own judgement in negotiating rates.

\begin{tabular}{lrrrr}
\hline Answer & Erequency & Percent & $\begin{array}{c}\text { Valid } \\
\text { Percent }\end{array}$ & $\begin{array}{c}\text { Cumulative } \\
\text { Percent }\end{array}$ \\
\hline Strongly Disagree & 23 & 18.30 & 18.30 & 18.30 \\
Disagree & 25 & 19.80 & 19.80 & 38.10 \\
Neutral & 20 & 15.90 & 15.90 & 54.00 \\
Agree & 43 & 34.10 & 34.10 & 88.10 \\
Strongly Agree & 15 & 11.90 & 11.90 & 100.00 \\
No Response & - & - & - & - \\
Total & 126 & 100.00 & 100.00 & - \\
\hline
\end{tabular}

\section{Table 23}

Responses to Question \#28

An individual guest will always pay the same rate for the same type of accommodations.

\begin{tabular}{lrrrr}
\hline Answer & Erequency & Percent & $\begin{array}{c}\text { Valid } \\
\text { Percent }\end{array}$ & $\begin{array}{c}\text { Cumulative } \\
\text { Percent }\end{array}$ \\
\hline Strongly Disagree & 42 & 33.30 & 33.30 & 33.30 \\
Disagree & 43 & 34.10 & 34.10 & 67.50 \\
Neutral & 13 & 10.30 & 10.30 & 77.80 \\
Agree & 14 & 11.10 & 11.10 & 88.90 \\
Strongly Agree & 14 & 11.10 & 11.10 & 100.00 \\
No Response & - & - & - & - \\
Total & 126 & 100.00 & 100.00 & - \\
\hline
\end{tabular}


Table 24

Responses to Question \#29

I am very familiar with the term "yield management."

\begin{tabular}{lrrrr}
\hline Answer & Frequency & Percent & $\begin{array}{c}\text { Valid } \\
\text { Percent }\end{array}$ & $\begin{array}{c}\text { Cumulative } \\
\text { Percent }\end{array}$ \\
\hline Strongly Disagree & 3 & 2.40 & 2.40 & 2.40 \\
Disagree & 3 & 2.40 & 2.40 & 4.80 \\
Neutral & 16 & 12.70 & 12.70 & 17.50 \\
Agree & 23 & 18.30 & 18.30 & 35.70 \\
Strongly Agree & 81 & 64.30 & 64.30 & 100.00 \\
No Response & - & - & - & - \\
Total & 126 & 100.00 & 100.00 & \\
\hline
\end{tabular}

Table 25

Responses to question \#30

I use yield management techniques extensively.

\begin{tabular}{lrrrr}
\hline Answer & Erequency & Percent & $\begin{array}{c}\text { Valid } \\
\text { Percent }\end{array}$ & $\begin{array}{c}\text { Cumulative } \\
\text { Percent }\end{array}$ \\
\hline Strongly Disagree & 5 & 4.00 & 4.00 & 4.00 \\
Disagree & 9 & 7.10 & 7.20 & 11.20 \\
Neutral & 27 & 21.40 & 21.60 & 32.80 \\
Agree & 43 & 34.10 & 34.40 & 67.20 \\
Strongly Agree & 41 & 32.50 & 32.80 & 100.00 \\
No Response & 1 & 0.80 & - & - \\
Total & 126 & 100.00 & 100.00 & - \\
\hline
\end{tabular}

Reproduced with permission of the copyright owner. Further reproduction prohibited without permission. 
Table 26

Responses to Question \#3I

I track room sales by market segment precisely.

\begin{tabular}{|c|c|c|c|c|}
\hline Answer & Erequency & Percent & $\begin{array}{l}\text { Valid } \\
\text { Percent }\end{array}$ & $\begin{array}{c}\text { Cumulative } \\
\text { Percent }\end{array}$ \\
\hline Strongly Disagree & 1 & 0.80 & 0.80 & 0.80 \\
\hline Disagree & 13 & 10.30 & 10.30 & $11 \cdot 10$ \\
\hline Neutral & 15 & 11.90 & 11.90 & 23.00 \\
\hline Agree & 40 & 31.70 & 31.70 & 54.80 \\
\hline Strongly Agree & 57 & 45.20 & 45.20 & 100.00 \\
\hline No Response & - & - & - & - \\
\hline Total & 126 & 100.00 & 100.00 & - \\
\hline
\end{tabular}

\section{Table 27}

Responses to Question \#32

I track denials and regrets by market segment precisely.

\begin{tabular}{lrrrr}
\hline Answer & Erequency & Percent & $\begin{array}{c}\text { Valid } \\
\text { Percent }\end{array}$ & $\begin{array}{c}\text { Cumulative } \\
\text { Percent }\end{array}$ \\
\hline Strongly Disagree & 23 & 18.30 & 18.30 & 18.30 \\
Disagree & 29 & 23.00 & 23.00 & 41.30 \\
Neutral & 27 & 21.40 & 21.40 & 62.70 \\
Agree & 23 & 18.30 & 18.30 & 81.00 \\
Strongly Agree & 24 & 19.00 & 19.00 & 100.00 \\
No Response & - & - & - & - \\
Total & 126 & 100.00 & 100.00 & - \\
\hline
\end{tabular}


Table 28

Responses to Question \#33

I always forecast future occupancy by market segment.

\begin{tabular}{lrrrr}
\hline Answer & Erequency & Percent & $\begin{array}{c}\text { Valid } \\
\text { Percent }\end{array}$ & $\begin{array}{c}\text { Cumulative } \\
\text { Percent }\end{array}$ \\
\hline Strongly Disagree & 11 & 8.70 & 8.70 & 8.70 \\
Disagree & 18 & 14.30 & 14.30 & 23.00 \\
Neutral & 26 & 20.60 & 20.60 & 43.70 \\
Agree & 33 & 26.20 & 26.20 & 69.80 \\
Strongly Agree & 38 & 30.20 & 30.20 & 100.00 \\
No Response & - & - & - & - \\
Total & 126 & 100.00 & 100.00 & - \\
\hline
\end{tabular}

Table 29

Responses to Question \#34

I am very aware of the demand patterns of each market segment.

\begin{tabular}{lrrrr}
\hline Answer & Erequency & Percent & $\begin{array}{c}\text { Valid } \\
\text { Percent }\end{array}$ & $\begin{array}{c}\text { Cumulative } \\
\text { Percent }\end{array}$ \\
\hline Strongly Disagree & 4 & 3.20 & 3.20 & 3.20 \\
Disagree & 8 & 6.30 & 6.30 & 9.50 \\
Neutral & 11 & 8.70 & 8.70 & 18.30 \\
Agree & 38 & 30.20 & 30.20 & 48.40 \\
Strongly Agree & 65 & 51.60 & 51.60 & 100.00 \\
No Response & - & - & - & - \\
Total & 126 & 100.00 & 100.00 & - \\
\hline
\end{tabular}

Reproduced with permission of the copyright owner. Further reproduction prohibited without permission. 
Table 30

Responses to Question \#35

I am very aware of the booking patterns of each market segment.

\begin{tabular}{lrrrr}
\hline Answer & Erequency & Percent & $\begin{array}{c}\text { Valid } \\
\text { Percent }\end{array}$ & $\begin{array}{c}\text { Cumulative } \\
\text { Percent }\end{array}$ \\
\hline Strongly Disagree & 24 & 19.00 & 19.20 & 19.20 \\
Disagree & 11 & 8.70 & 8.80 & 28.00 \\
Neutral & 30 & 23.80 & 24.00 & 52.00 \\
Agree & 33 & 26.20 & 26.40 & 78.40 \\
Strongly Agree & 27 & 21.40 & 21.60 & 100.00 \\
No Response & 1 & 0.80 & - & - \\
Total & 126 & 100.00 & 100.00 & - \\
\hline
\end{tabular}


From the foregoing data, a "count" was calculated for each respondent. This represents the total number of the essential elements of yield management being practiced by the general manager. Table 31 contains a frequency distribution of this data.

Table 31

Number of YM Essential Elements Used

\begin{tabular}{lrrrr}
\hline $\begin{array}{l}\text { Number of } \\
\text { Elements Used }\end{array}$ & Erequency & Percent & $\begin{array}{r}\text { Valid } \\
\text { Percent }\end{array}$ & $\begin{array}{c}\text { Cumulative } \\
\text { Percent }\end{array}$ \\
\hline 0 of 8 & 5 & 4.00 & 4.00 & 4.00 \\
1 of 8 & 13 & 10.30 & 10.30 & 14.30 \\
2 of 8 & 16 & 12.70 & 12.70 & 27.00 \\
3 of 8 & 21 & 16.70 & 16.70 & 43.70 \\
4 of 8 & 21 & 16.70 & 16.70 & 60.30 \\
5 of 8 & 27 & 21.40 & 21.40 & 81.70 \\
6 of 8 & 17 & 13.50 & 13.50 & 95.20 \\
7 of 8 & 6 & 4.80 & 4.80 & 100.00 \\
8 of 8 & 0 & 0.00 & 0.00 & 100.00 \\
Total & 126 & 100.00 & 100.00 & - \\
\hline
\end{tabular}


Hypothesis Testing

Each hypothesis is stated in terms of a possible relationship with the perception of the general manager as regards his or her own use of yield management techniques. As stated in chapter 2, the literature indicates that there is not a consensus among rate setters as to what practices constitute yield management. Researchers, on the other hand, have proposed that yield management in hotels would ideally consist of the eight elements identified in chapter 1 . In other words, the following tests measure how well the perceptions of the general managers match their actual use of yield management techniques as defined herein.

General managers were divided into two groups. Those who "agreed" or "strongly agreed" with the statement "I use yield management techniques extensively," were classified as "high" in their perception of their own yield management behavior. All others were classified as "Low."

Likewise, for purposes of crosstabulation and chisquare testing, each test variable was also summarized in two groups. Those who "agreed" or "strongly agreed" that they use each element were classified as "high" as pertaining to that practice. All others were classified as "Low." 
Hypothesis 1 .

The null hypothesis can be rejected at the $95 \%$

confidence level. The number of elements of yield management practiced appears to be related to the general managers'

perceptions of their utilization of yield management

techniques.

Table 32

Cross Tabulation of Number of Essential Elements Used by GM's Perception of YM Behavior

\begin{tabular}{|c|c|c|c|c|}
\hline \multirow[t]{2}{*}{$\begin{array}{l}\text { Number of } \\
\text { Elements Used }\end{array}$} & \multicolumn{2}{|c|}{$\begin{array}{l}\text { GM's Perception } \\
\text { of YM Behavior }\end{array}$} & \multirow[b]{2}{*}{ Row } & \multirow[b]{2}{*}{ Total } \\
\hline & LOW & $\mathrm{HIGH}$ & & \\
\hline $0-4$ & 35 & 40 & & 75 \\
\hline $5-8$ & 6 & 44 & & 50 \\
\hline Column Total & 41 & 84 & & 125 \\
\hline
\end{tabular}

*Chi-Square Value $=16.35695$

Significance

$=.00005$

*Pearson's R Value $=.36174$

Significance

$=.00003$ 
Hypothesis 2 .

The null hypothesis cannot be rejected at the 95\%

confidence level. The rate setters' propensity to segment customers by willingness to pay appears to be unrelated to their perceptions of their utilization of yield management techniques at the 95 웅 level. The relationship does appear to be significant, however, at the $90 \%$ confidence level.

Table 33

Cross Tabulation of Willingness to Pay by $\mathrm{GM}^{\prime}$ s Perception of YM Behavior

\begin{tabular}{|c|c|c|c|c|}
\hline \multirow{2}{*}{$\begin{array}{l}\text { Segment by } \\
\text { Willingness to } \\
\text { Pay }\end{array}$} & \multicolumn{2}{|c|}{$\begin{array}{l}\text { GM's Perception } \\
\text { of } Y M \text { Behavior }\end{array}$} & \multirow[b]{2}{*}{ Row } & \multirow[b]{2}{*}{ Total } \\
\hline & LOW & $\mathrm{HIGH}$ & & \\
\hline LOW & 24 & 36 & & 60 \\
\hline HIGH & 13 & 40 & & 53 \\
\hline Column Total & 37 & 76 & & 113 \\
\hline
\end{tabular}

$\begin{aligned} \text { *Chi-Square value } & =3.05891 \text { Significance }=.08030 \\ { }^{*} \text { Pearson's } \mathrm{R} \text { value } & =.16453 \text { Significance }=.08161\end{aligned}$

Reproduced with permission of the copyright owner. Further reproduction prohibited without permission. 
Hypothesis 3 .

The null hypothesis can be rejected at the 95\%

confidence level. The rate setters' propensity to track

booking patterns by segment appears to be related to their

perceptions of their utilization of yield management

techniques.

Table 34

Cross Tabulation of Booking Patterns by GM's Perception of YM Behavior

\begin{tabular}{lrrr}
$\begin{array}{l}\text { Track Booking } \\
\text { Patterns by } \\
\text { segment }\end{array}$ & \multicolumn{2}{c}{$\begin{array}{l}\text { GM' } \\
\text { Of }\end{array}$} & YM Berception \\
& LOW & HIGH & Row Total \\
\cline { 2 - 4 } & 30 & 35 & 64 \\
LOW & 11 & 48 & 59 \\
HIGH & 41 & 83 & 124
\end{tabular}

$\begin{array}{llll}* \text { Chi-Square Value } & =10.57546 & \text { Significance } & =.00115 \\ * \text { Pearson's R Value }=.29204 & \text { Significance } & =.00100\end{array}$


Hypothesis 4 .

The null hypothesis can be rejected at the $95 \%$

confidence level. The rate setters' propensity to track

demand patterns by segment appears to be related to their

perceptions of their utilization of yield management

techniques.

Table 35

Cross Tabulation of Demand Patterns by GM's Perception of YM Behavior

\begin{tabular}{lrrr}
$\begin{array}{l}\text { Track Demand } \\
\text { Patterns by } \\
\text { segment }\end{array}$ & \multicolumn{2}{c}{$\begin{array}{c}\text { GM's Perception } \\
\text { of YM Behavior }\end{array}$} & \\
\cline { 2 - 4 } & LOW & HIGH & Row Total \\
\hline LOW & 15 & 8 & 23 \\
HIGH & 26 & 76 & 102 \\
Column Total & 41 & 84 & 125
\end{tabular}

$\begin{array}{llll}{ }^{\star C h i-S q u a r e} \text { Value } & =13.43850 & \text { Significance } & =.00025 \\ * \text { Pearson's R Value }=.32788 & \text { Significance } & =.00019\end{array}$


Hypothesis 5 .

The nuIl hypothesis can be rejected at the 95\%

confidence level. The rate setters' propensity to track room sales by segment appears to be related to their perceptions of their utilization of yield management techniques.

\section{Table 36}

Cross Tabulation of Sales by GM's Perception of YM Behavior

\begin{tabular}{lrrr}
$\begin{array}{l}\text { Track Sales by } \\
\text { Segment }\end{array}$ & \multicolumn{2}{c}{$\begin{array}{c}\text { GM' S Perception } \\
\text { Of YM }\end{array}$} & Behavior \\
\cline { 2 - 4 } & LOW & HIGH & Row Total \\
\hline LOW & 19 & 10 & 29 \\
HIGH & 22 & 74 & 96 \\
Column Total & 41 & 84 & 125
\end{tabular}

*Chi-Square Value $=18.33779$

Significance $=.00002$

*Pearson's R Value $=.38302$

Significance $=.00001$ 
Hypothesis 6 .

The null hypothesis can be rejected at the 95\%

confidence level. The rate setters' propensity to track

denials and regrets by segment appears to be related to

their perceptions of their utilization of yield management

techniques.

Table 37

Cross Tabulation of Denials \& Regrets by GM's Perception of YM Behavior

\begin{tabular}{lrrr}
\begin{tabular}{l} 
Track Denials $\begin{array}{l}\text { \&egrets by } \\
\text { Segment }\end{array}$ \\
\cline { 2 - 4 }
\end{tabular} & $\begin{array}{l}\text { GM's Perception } \\
\text { of YM Behavior }\end{array}$ & \\
\cline { 2 - 4 } & LOW & HIGH & Row Total \\
\hline LOW & 34 & 44 & 78 \\
HIGH & 7 & 40 & 47 \\
Column Total & 41 & 84 & 125
\end{tabular}

\begin{tabular}{llll}
\hline *Chi-Square Value & $=.1095685$ & Significance & $=.00093$ \\
$*$ Pearson's R Value & $=.29607$ & Significance & $=.00080$
\end{tabular}

Reproduced with permission of the copyright owner. Further reproduction prohibited without permission. 
Hypothesis 7.

The nuIl hypothesis can be rejected at the 95\%

confidence level. The rate setters' propensity to forecast

future occupancy by segment appears to be related to their

perceptions of their utilization of yield management

techniques.

Table 38

Cross Tabulation of Occupancy Eorecast by GM's Perception of YM Behavior

$\begin{array}{ll}\text { Eorecasts } & \text { GM's Perception } \\ \text { Occupancy by } & \text { of YM Behavior }\end{array}$

Segment

\begin{tabular}{lrrr}
\cline { 2 - 4 } & LOW & HIGH & Row Total \\
\hline LOW & 29 & 26 & 55 \\
HIGH & 12 & 58 & 70 \\
Column Total & 41 & 84 & 125 \\
\hline
\end{tabular}

*Chi-Square Value $=17.69405$

Significance $=.00003$

*Pearson's R Value $=.37623$

Significance $=.00002$ 
Hypothesis 8 .

The mean ratio of marginal sales cost to price floor was compared for two groups of respondents. General managers who perceived that they used yield management techniques extensively were placed in the "high" group, all others were placed in the "Iow" group. Results of the independent samples, one-tailed t-test are shown in table 39.

The null hypothesis cannot be rejected at the $95 \%$ confidence level. The average ratio of marginal sales cost to price floor is not significantly larger for rate setters who perceive that they use yield management techniques extensively than it is for those who perceive that they do not use yield management techniques extensively. 


\section{Table 39}

One-tailed $t$-test for independent samples of the Ratio of marginal sales cost to price floor grouped by GM's Perception of YM Behavior.

\begin{tabular}{lrrr}
$\begin{array}{l}\text { GM's } \\
\text { Perception } \\
\text { of YM } \\
\text { Behavior }\end{array}$ & Cases & $\begin{array}{r}\text { Mean } \\
\text { Ratio }\end{array}$ & SD \\
\hline LOW & 33 & 0.37480 & 0.11600 \\
HIGH & 69 & 0.36770 & 0.15700
\end{tabular}

* Difference in Means

$=0.00710$

*Calculated t-value

$=0.693$ Significance

$=0.4866$ 
Hypothesis 9.

The null hypothesis can be rejected at the 95\%

confidence level. The rate setters' propensity to use an

optimal room allocation method appears to be related to

their perceptions of their utilization of yield management

techniques.

Table 40

Cross Tabulation of Optimal Allocation by $\mathrm{GM}^{\prime}$ 's Perception of YM Behavior

\begin{tabular}{lrrr}
$\begin{array}{l}\text { Uses an Optimal } \\
\text { Room Allocation } \\
\text { Technique }\end{array}$ & $\begin{array}{l}\text { GM's Perception } \\
\text { of YM Behavior }\end{array}$ & \\
\cline { 2 - 3 } & LOW & HIGH & Row Total \\
\hline NO & 21 & 33 & 54 \\
YES & 3 & 31 & 34 \\
Column Total & 24 & 64 & 88
\end{tabular}

${ }^{*}$ Chi-Square Value $=9.50817$ Significance $=.00205$

${ }^{\star}$ Pearson's R Value $=.32871$ Significance $=.00177$ 


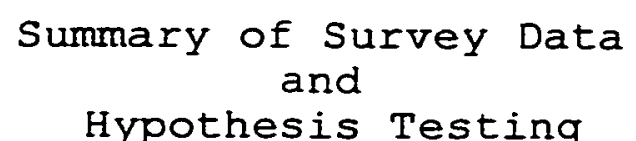

There were 126 valid surveys in this study. $33.6 \%$ of the respondents represented major chain hotels. $28 \%$ worked for multi-brand management companies, and $38.4 \%$ represented independent hotels. The mean size of the hotels represented in the survey was 251 rooms. The mean occupancy was 69\% and the mean average daily rate was $\$ 89.95$. A majority of the respondents $(76.9 \%)$ said that they use yield management techniques extensively, while the remainder said that they do not use them extensively.

On average, general managers use 3.7 of the 8 essential elements of yield management. Those who claim to practice yield management use a median 5 of the 8 elements, while those who do not claim to be using yield management use a median 2 of the 8 elements.

The results of the hypothesis testing revealed that:

$\diamond \quad$ A significant relationship exists between a general manager's perceptions of yield management behavior and the number of the elements of yield management that are utilized.

$\diamond \quad$ A significant relationship does not exist between a general manager's perceptions of yield management behavior and the practice of segmenting customers by willingness or ability to pay. 
$\diamond \quad$ A significant relationship exists between a general manager's perceptions of yield management behavior and the practice of tracking booking patterns by market segment.

$\diamond \quad$ A significant relationship exists between a general manager's perceptions of yield management behavior and the practice of tracking demand patterns by market segment.

$\diamond \quad$ A significant relationship exists between a general manager's perceptions of yield management behavior and the practice of tracking sales by market segment.

$\diamond \quad$ A significant relationship exists between a general manager's perceptions of yield management behavior and the practice of tracking denials and regrets by market segment.

$\diamond \quad$ A significant relationship exists between a general manager's perceptions of yield management behavior and the practice of tracking booking patterns by market segment.

$\diamond \quad$ A significant relationship exists between a general manager's perceptions of yield management behavior and the practice of forecasting future occupancy by market segment. 
$\diamond \quad$ A significant relationship does not exist between a general manager's perceptions of yield management behavior and the practice of setting the price floor close to the marginal sales cost.

$\diamond \quad$ A significant relationship exists between a general manager's perceptions of yield management behavior and the practice of using an optimal room allocation technique.

The following table gives the results of the hypothesis testing in summary format. 
Table 41

Summary of hypothesis testing

\begin{tabular}{|c|c|c|}
\hline & Research Hypothesis & Results \\
\hline $\mathrm{HI}$ & $\begin{array}{l}\text { Managers who practice YM utilize more } \\
\text { of the essential elements of YM than } \\
\text { managers who do not. }\end{array}$ & $\begin{array}{l}\text { A significant relationship was found to exist } \\
\text { at the } 95 \% \text { confidence level. }\end{array}$ \\
\hline $\mathrm{H} 2$ & $\begin{array}{l}\text { Managers who practice YM segment } \\
\text { their customers by willingness to } \\
\text { pay. }\end{array}$ & $\begin{array}{l}\text { No relationship could be established at the } \\
95 \% \text { confidence level, but the relationship } \\
\text { was significant at the } 90 \% \text { confidence level. }\end{array}$ \\
\hline H3 & $\begin{array}{l}\text { Managers who practice YM track } \\
\text { booking patterns by market segment. }\end{array}$ & $\begin{array}{l}\text { A significant relationship was found to exist } \\
\text { at the } 95 \% \text { confidence level. }\end{array}$ \\
\hline $\mathrm{H} 4$ & $\begin{array}{l}\text { Managers who practice YM track demand } \\
\text { patterns by segment. }\end{array}$ & $\begin{array}{l}\text { A significant relationship was found to exist } \\
\text { at the } 95 \% \text { confidence level. }\end{array}$ \\
\hline H5 & $\begin{array}{l}\text { Managers who practice YM track sales } \\
\text { by segment. }\end{array}$ & $\begin{array}{l}\text { A significant relationship was found to exist } \\
\text { at the } 95 \% \text { confidence level. }\end{array}$ \\
\hline H6 & $\begin{array}{l}\text { Managers who practice YM track } \\
\text { denials and regrets by segment. }\end{array}$ & $\begin{array}{l}\text { A significant relationship was found to exist } \\
\text { at the } 95 \% \text { confidence level. }\end{array}$ \\
\hline H7 & $\begin{array}{l}\text { Managers who practice YM forecast } \\
\text { occupancy by market segment. }\end{array}$ & $\begin{array}{l}\text { A significant relationship was found to exist } \\
\text { at the } 95 \% \text { confidence level. }\end{array}$ \\
\hline $\mathrm{H} 8$ & $\begin{array}{l}\text { Managers who practice } Y M \text { fix the } \\
\text { absolute price floor close to the } \\
\text { marginal sales cost. }\end{array}$ & $\begin{array}{l}\text { No relationship could be established at the } \\
95 \% \text { confidence level. }\end{array}$ \\
\hline $\mathrm{H} 9$ & $\begin{array}{l}\text { Managers who practice YM utilize some } \\
\text { optimal room allocation technique. }\end{array}$ & $\begin{array}{l}\text { A significant relationship was found to exist } \\
\text { at the } 95 \% \text { confidence level. }\end{array}$ \\
\hline
\end{tabular}




\section{CHAPTER 5}

\section{DISCUSSION AND CONCLUSION}

This study attempted to analyze the influence of yield management on the pricing practices of hotel general managers in the United States in 1997. It found that a very large majority of general managers $(82.6 \%)$ are either familiar or very familiar with the concept of yield management. Of all respondents $76.9 \%$ said that they use yield management techniques extensively.

Much of the existing research on yield management in hotels has concluded that there are distinct procedural elements that make up the practice. This research has combined previous lists to propose that yield management in hotels consists of the eight elements Iisted in chapter 1 . The study found that there was a positive relationship between a manager's perception of his or her own yield management behavior and the number of the essential elements used. In looking at the relationship more closely, it was found that there was also a relationship between the manager's perception and the utilization of the following specific practices:

1. Tracking booking patterns by segment. 
2. Tracking demand patterns by segment.

3. Tracking sales by segment.

4. Tracking denials and regrets by segment.

5. Eorecasting occupancy by segment.

6. Using some optimal room allocation technique.

In other words, managers who believe that they are using yield management are more likely to do these six things than are managers who do not believe that they are using yield management.

In the case of two of the eight elements, there is not a significant relationship. Managers who practice yield management are no more likely to:

1.) segment customers by willingness to pay, or

2.) fix the price floor close to the marginal sales cost

than are managers who do not practice yield management. It is interesting to note that these are the two elements of yield management that are most directly related to price.

Overall, yield management is a major factor in hotel room pricing in 1997. A large percentage of general managers (39.7\%) use 5 or more of the elements of yield management. Not one manager in the sample, however, used all eight elements. The study also found that large minorities, and in some cases a majority, of YM practitioners do not practice individual elements of yield management as table 42 
indicates.

Clearly, there is not one, accepted practical

definition of yield management in hotels. It seems that, as Lieberman (1993, p. 34) suggested "if you ask ten hoteliers what it is, you are apt to get at least five, and possibly ten, different answers."

\section{Table 42}

Ratio of YM practitioners who use each element extensively.

\begin{tabular}{lll}
\hline Of those who practice yield management: & High & Low \\
\hline Segments by willingness to pay. & $53 \%$ & $47 \%$ \\
Tracks booking patterns by segment. & $58 \%$ & $42 \%$ \\
Tracks demand patterns by segment. & $90 \%$ & $10 \%$ \\
Tracks sales by segment. & $88 \%$ & $12 \%$ \\
Tracks denials and regrets by segment. & $48 \%$ & $52 \%$ \\
Eorecasts occupancy by segment. & $69 \%$ & $31 \%$ \\
Will sell a room for less than 200\% of its & $36 \%$ & $64 \%$ \\
marginal seling cost under some & & \\
circumstance. & $48 \%$ & $52 \%$ \\
Allocates rooms in some optimal way. & & \\
\hline
\end{tabular}

Survey Limitations

and Sources of Bias

Although this study attempted to collect data from a random and representative sample of United States hotel general managers, there were factors that may have 
interfered with this. The sample was drawn only from the Who's who in the Hospitality Industry and the Hotel and Travel Index as previously explained. These two sources do not contain the entire population of hotels and motels in the United States.

The study may have also introduced survey bias because of the low response rate. With only 126 responses in 1,247 attempts, there could easily be differences in the yield management perceptions and practices between those who refused to participate and those who agreed to participate in the survey.

To test for differences between respondents and nonrespondents, a chi-square test was conducted. The test revealed that at the $95 \%$ confidence level, there was no difference between the number of YM elements used by those who responded by mail, and those who were contacted by telephone. The results are shown in appendix $B$.

Limited funding prevented two measures that would probably have produced a better result. A pre-test of the survey instrument might have resulted in a higher response rate. An incentive payment to respondents might also have promoted more participation. 


\section{Representativeness \\ of the Survey Sample.}

Some of the survey data collected for this paper was found to be similar to survey data collected by Pannell Kerr, and Forster for their annual Trends in the Hospitality Industry report (PKE Consulting, 1995).

To determine the significance of the differences between the PKF data and the data obtained by this survey, t-tests were conducted to compare the means as indicated in table 43. If the null hypothesis in each case is that there is no difference between the mean of the PKE sample and the mean of this survey sample, the following conclusions may be reached.

1. The null hypothesis can be rejected with $95 \%$ confidence as regards hotel size.

2. The null hypothesis cannot be rejected with $95 \%$ confidence as regards occupancy.

3. The null hypothesis cannot be rejected with $95 \frac{0}{5}$ confidence as regards average room rate.

Although these tests are inconclusive, they justify an assumption of representativeness. 
Table 43

Comparison with other survey data

\begin{tabular}{lllc}
\hline Mean & Survey Data & PKE Data & 2 tail sig. \\
\hline Hotel Size & 251 rooms & 210 rooms & .023 \\
Occupancy & $69.5 \%$ & 69.48 & .937 \\
Average Rate & $\$ 89.95$ & $\$ 83.03$ & .162 \\
\hline
\end{tabular}

Implications

for the Hotel Industry

The hotel industry in 1997 faces a very favorable supply / demand relationship. As the airline experience illustrates, it is precisely in such an environment that yield management produces the greatest benefits. It is ironic, however, that while general managers know about yield management and claim to use it, they are not using all of the tools available to them to maximize revenues. Why is this? There are several possible reasons.

\section{Legal Challenges}

The survey results indicate that even managers who understand and utilize yield management may be reluctant to segment customers primarily by willingness to pay. Other researchers have pointed out that there are potential legal problems with doing this. Griffin (1995) pointed out that more and more claims of false advertising are being brought 
against airlines resulting from "yield management price juggling."

Some legal scholars have even suggested that discriminate pricing, which is the concept behind yield management, is basically a fraudulent and misleading business practice.

The prices at which competing goods and services are sold is information that consumers must have if their collective decisions are to fuel the workings of a perfectly competitive market. Thus, if a market failure obstructs the flow of price information in a significant way, we have a prime candidate for an unfairness challenge. (Pridgen, 1988).

In other words, it may be illegal to tell a low-rate guest that rooms are not available, while simultaneously holding rooms for potential higher-rate business. "Eailure to disclose existing prices when asked, refusing to sell what is promoted ... or providing incorrect or erroneous information could be considered violations of the unfair and deceptive acts and practices legislation" (Wilson, 1992, p. 22).

\section{Marketing Considerations}

Griffin (1995) has concluded that the natural inclination of yield management systems is to be very 
responsive in the short run but that they lack consideration for long-term strategies. General managers may refuse to utilize some aspects of yield management because they fear the long-term consequences of segmenting customers primarily by willingness to pay. They may fear that customers will object to this strategy when it becomes known to them.

There is good reason to be concerned. In a study on the perceived fairness of yield management pricing strategies, Kimes discovered that "many common practices used in the hotel industry were viewed as highly unacceptable by the survey respondents" (Kimes, 1994, p. 22). It seems reasonable to assume that customers who think that yield management is "unfair" might choose to patronize hotels that don't use its more offensive elements. This would certainly erode yield management's value in the long run, and erase its short-term benefits.

Travel agents and other third-party bookers are often opposed to yield management. Their job is to provide value and consistency for their clients. Travel agents don't like it when they obtain a rate for a client that turns out to be higher than the client could have received for him or herself. Travel agents want hotels to provide what they call "tariff integrity." In writing on this subject, one travel agent declared that "it should be obvious that your mission as an agent is squarely in opposition to the objectives of 
supplier yield management.." (Wardell, 1989, p. 75).

This research has also shown that general managers do not establish a price floor that is very close to the marginal sales cost. They apparently do not agree with orkin (1988) that to sell a room for even one cent more than its marginal sales cost is preferable to letting the room remain vacant. This may be due to the managers' perception that the price of the product is largely an extrinsic indicator of quality and value (Shaw, 1992). Again, they may see heavy discounting as detrimental to the long-term marketing goals of the hotel.

The airline experience is instructive here. It can be argued that yield management has erased most of the qualitative distinctions between airlines. In many ways airline travel has become a commodity that competes on price only. There is certainly a much broader range of product in the hotel industry.

\section{Human Resources}

Yield management, pursued aggressively, can have negative effects on a general manager's own career and income. In investigating this very question, Gamble (1990, p. 19) concluded that "at the end of the day, 1008 full is safe ... anything other than $100 \%$ is dangerous in career terms" . Likewise, sales people generally receive incentives 
based on total rooms booked.

Until incentives are modified to reward employees for bookings based on their comparative value to the hotel, the employees may short circuit the strategy. They will do this by over booking groups at medium rates because that is where the bulk of the demand is. This will make rooms unavailable for late-booking high-rate guests. Hotels will then be less likely to discount their last rooms heavily when necessary because there aren't enough high rate rooms to produce an acceptable average rate.

Finally, yield management is a complex undertaking. When this complexity is coupled with the notorious turnover rate among hotel employees, general managers may feel that it is best to implement only simplified versions.

\section{Information}

There is a possibility that some of the elements of yield management are poorly utilized because information systems currently in use do not make the data easily available. For example, less than half of the general managers who say they practice yield management extensively track denials and regrets by market segment. It seems likely that they might fail to take this step because their CRS systems do not track this information. It would require some supplemental procedure to track denials and regrets in this 
way. Managers may be facing a tradeoff between improved yield management effectiveness and increased complexity and training. Many would seem to be choosing simplicity.

\section{Summary}

Yield management is a popular topic in the hotel industry. Hoteliers have looked at the airlines and their claims of improving revenues by $2 \frac{\circ}{6}-5 \frac{5}{2}$, and have been enthusiastic about attempting to do the same. This research has found that most hotel managers say that they are using yield management techniques extensively - and many are. When yield management is broken down into its component parts, however, there are some gaps between perception and reality. General managers seem reluctant to fully implement some of the elements of yield management. This paper has speculated as to why that might be. Eurther research is needed to confirm or refute those speculations. 
APPENDIX A

SURVEY QUESTIONNAIRE

AND

COVER LETTER

93

Reproduced with permission of the copyright owner. Further reproduction prohibited without permission. 


\section{Dear Sir or Madam,}

Yield management is a topic that has generated a lot of attention in the hospitality industry in recent years; yet, little is known about the extent of its influence among those who actually set hotel room rates. One researcher has given his opinion that "if you ask ten different managers what yield management is, you will likely get at least five different answers -- maybe ten."

I was a General Manager myself for several years, and I'm now a graduate student at the University of Nevada, Las Vegas. I am conducting this study in partial fulfillment of the requirements for a Master's degree. Its purpose is to obtain information regarding the perceptions and practices of those who set room rates in the hotel industry. I am particularly interested in the extent to which the principles of yield management are being utilized. I have identified you as one who has practical expertise in this area. Would you please take a few moments to fill out the enclosed questionnaire and return it in the postage-paid, return envelope that is also enclosed? Your responses will be completely confidential. I will be happy to return the compiled results of this survey to you if you enclose your business card with your completed survey form.

I believe that you will find the questions to be self-explanatory with the possible exception of number 20. This question asks you to state your opinion regarding maximum possible revenue vs. optimal revenue. To clarify this question: maximum possible revenue is defined as $100 \%$ occupancy at rack rate, while optimal revenue is a mathematically calculated, target REVPAR that considers the actual supply and demand conditions that prevail in your market.

Thank you in advance for your willingness to take a few minutes out of your busy schedule to help with this research. Your assistance will make it possible for industry executives, software developers and educators to better understand how rates are set in our industry in 1997. If you have questions about this research, or the confidentiality of the data you provide, you may contact either myself or the Office of Sponsored Programs as indicated below.

Sincerely,

Jeff Caneen 
1. How many total rooms are there in your hotel?

2. What type of management organization do you work for?

A major chain (i.e. Hilton)

A multi-brand management company (i.e. Larkin)

An independent operation (anything other than above)

3. Your property can best be classified as:

full-service limited-service all-suite

4. Your property can best be classified as : commercial convention resort extended stay

5. Your property can best be classified as: luxury mid-market economy

6. What is your estimate of the overall annual hotel occupancy in your market?

Less than $65 \%$ $75 \%-80 \%$
$65 \%-70 \%$ more than $80 \%$ $70 \%-75 \%$

7. What was your average room rate for 1996 ?

8. What was your standard rack rate for 1996 ?

9. Approximately what percentage of your rooms are sold at rack rate?

10. What is the total room tax percentage at your hotel?

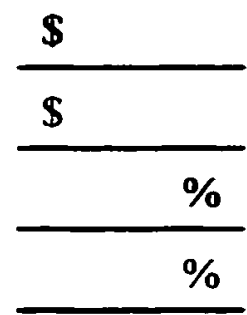

11. What was your REVPAR (total room revenue / total available room nights) for 1996 ?

12. How do you determine rack rate?

Arbitrarily

Survey of the competition

Last year's rack rate + some \%
Market research

Other (explain)

13. What is your marginal cost to sell an additional room (how much more does it cost to sell it than to leave it empty: cleaning, etc.)?

14. What is the lowest rate for which you will sell your most common room type?

$\frac{\$}{\$}$

15. How many years' experience do you have in the industry?

16. How many years' experience do you have as a G.M.?

17. How would you characterize your education?

High school graduate

Bachelor's degree in a hospitality field

Some college

Bachelor's degree in some other field

Advanced degree 
18. "Yield" has been defined as the ratio of actual total room revenue to the maximum possible room revenue which is the product of rack rate at $100 \%$ occupancy. (For example: a 100 room hotel with a rack rate of $\$ 90$ will have a maximum possible room revenue of $\$ 9,000 /$ day. If actual room revenue for 1 day was $\$ 4,500$, the yield would be $50 \%$.) To what extent do you practice yield management based on this definition?

$1=$ "not at all" $\quad 5=$ "a great deal" $\quad$ (circle your answer here $\boldsymbol{m}$ ) $\quad \begin{array}{llllll}1 & 2 & 3 & 4 & 5\end{array}$

19. In your opinion, which of the following definitions better describes the essence of "yield" as it relates to hotel room sales?

Yield is the ratio of actual total room revenue to maximum possible room revenue as described above.

Yield is the ratio of actual room revenue to optimum room revenue under given supply and demand conditions.

20. Do you use an automated yield management system?

Yes No

21. If yes, what is the brand name of the system?

22. In your inventory management efforts, which of the following do you attempt to maximize?

$\begin{array}{ll}\text { Total Revenue } & \text { Occupancy } \\ \text { ADR } & \text { REVPAR } \\ \text { Yield } & \text { Other }\end{array}$

23. Rank the following in order of their importance in segmenting your customers

$(1=$ most important, 5 = least important $)$ :

Purpose of their visit

Length of time prior to arrival that the reservation is made

Type of accommodations typically required

Willingness / ability to pay

Other (explain)

24. Do you allocate the rooms available for sale to each segment?

Yes No

25. If yes, how do you allocate the rooms available for sale to each segment?

First come, first served

Fixed allocation for each segment

Threshold curve

Mathematic formula

Intuitive

Other (explain) 
For questions 26 - 36, please circle the number that best represents your level of agreement with each statement. 1 = "strongly disagree" 2 = "disagree" $3=$ "neither agree nor disagree"

$$
4=\text { "agree" } 5=\text { "strongly agree" }
$$

26. As G.M., I have complete autonomy in setting room rates.

$\begin{array}{lllll}1 & 2 & 3 & 4 & 5\end{array}$

27. I allow the desk staff and reservations staff to use their own judgement in negotiating rates.

28. An individual guest will always pay the same rate for the same type of accommodations.

29. I am very familiar with the term "yield management."

30. I use yield management techniques extensively

31. I track room sales by market segment precisely.

$\begin{array}{lllll}1 & 2 & 3 & 4 & 5\end{array}$

$\begin{array}{lllll}1 & 2 & 3 & 4 & 5\end{array}$

$\begin{array}{lllll}1 & 2 & 3 & 4 & 5\end{array}$

$\begin{array}{lllll}1 & 2 & 3 & 4 & 5\end{array}$

$\begin{array}{lllll}1 & 2 & 3 & 4 & 5\end{array}$

32. I track denials and regrets by market segment precisely.

("Denials \& regrets" are requests for reservations that are aborted because of $1 \begin{array}{lllll}1 & 2 & 3 & 4 & 5\end{array}$ price or availability.)

33. I always forecast future occupancy by market segment.

34. I am very aware of the demand patterns of each market segment. ("Demand pattern" refers to demand by season, day of the week, etc)

$\begin{array}{lllll}1 & 2 & 3 & 4 & 5\end{array}$

$\begin{array}{lllll}1 & 2 & 3 & 4 & 5\end{array}$

35. I am very aware of the booking patterns of each market segment. ("Booking pattern" refers to the length of time prior to arrival that reservations are typically made.)

$\begin{array}{lllll}1 & 2 & 3 & 4 & 5\end{array}$

36. I would be very interested in using a measure of yield management that would compare my actual REVPAR to a calculated optimal REVPAR for my hotel.

37. I know that this is asking a lot, but would you please provide daily room sales statistics (rooms sold, average rate) for the most recent 8 week period for which you have such statistics compiled? Please also indicate any special events that caused unusually high or low occupancy for any of these days. This data will be used to estimate the optimal average rate that may lead to optimal REVPAR for your operation under existing supply and demand conditions. This data will, of course, be kept completely confidential. The result will be mailed back to you if you enclose your business card. Please send the data in spreadsheet format (on a diskette if possible). If you choose not to take the time to supply this information, PLEASE send in the completed survey form without it.

Yes, I'm sending the data, please return the results.

No, I'm not willing to share this data.

Thande you wery meche for youer time 
APPENDIX B

COMPARISON OE RESPONDENTS

AND

NON-RESPONDENTS

98

Reproduced with permission of the copyright owner. Further reproduction prohibited without permission. 
Table 44

Cross Tabulation of Number of Elements Used by Type of Respondent.

\begin{tabular}{lrrr}
\multirow{2}{*}{$\begin{array}{l}\text { YM Elements } \\
\text { Used }\end{array}$} & \multicolumn{2}{c}{ Respondent } \\
\cline { 2 - 3 } & Mail & Phone & Row Total \\
\hline $0-4$ Elements & 48 & 27 & 75 \\
$5-8$ Elements & 36 & 15 & 51 \\
Column Total & 84 & 42 & 126
\end{tabular}

*Chi-Square Value $=.77824$ Significance $=.37768$

*Pearson's R Value $=.07859$ Significance $=.38171$ 
References

American Hotel and Motel Assoc. (1952). The Hubert Eormula for Evaluating Rate structures of Hotel Rooms. New York: American Hotel Association.

Andrew, William P. (1990). Forecasting Hotel Occupancy Rates with Time Series Models: An Empirical Analysis. Hospitality Research Journal. 14, 2, 173-182. Badinelli, Ralph D. \& Olsen, Michael D. (1990). Hotel Yield Management Using Optimal Decision Rules. Journal of the Academy of Hospitality Research. 1, 1, 1-35. Baker, T.K. (1994). New Approaches To Yield Management: Comprehensive Overbooking / Allocation Heuristics For The Hotel Industry. Dissertation. Ohio State University. Belobaba, Peter P. (1989). Application of A Probabalistic Decision Model To Airline Seat Inventory Control. operations Research 37, 2, 183-197. Bitran, Gabriel R. and Mondschein, Susan V. (1995). An Application of Yield Management To The Hotel Industry Considering Multiple Day Stays. Operations Research 43 , $3,427-443$. Brumelle, Shelby et. al. (1990). Allocation of Airline seats Between Stochastically Dependent Demands. Transportation Science 24, 3, 183-192. 
Brumelle, Shelby and McGill, J. (1993). Airline seat

Allocation with Multiple Nested Fare Classes. Operations Research 41, 1, 127-137.

Dillon, Madden and Firtile. (1994). Marketing research in a Marketing Environment. $3^{\text {rd }}$ Ed. Boston: Irwin. Donaghy, Kevin. (1995). Yield Management: An Overview.

International Journal of Hospitality Management. 14,2. Dunn, Kate D. and Brooks, David E. (1990). Profit Analysis: Beyond Yield Management. The Cornell Hotel \& Restaurant Administration Ouarterly. 80-90. Gallacher, Jackie. (1995). Pricing It Right. Airline

Business. 11, 2, 40-43. Gamble, Paul R. (1990). Building A Yield Management System The Flip Side. Hospitality Research Journal. 14,2, 11-22. Glab, Jim. (1992). Tariff Integrity: Restoring Sanity to

Hotel Rates. ASTA Agency Management. 61, 8, 30+. Griffin, Robert K. (1994). Critical Success Factors of

Lodging Yield Management Systems: an Empirical Study.

Dissertation: Virginia Polytechnic Institute. Griffin, Robert K. (1995). A Categorization Scheme for Critical Success Factors of Lodging Yield Management Systems. International Journal of Hospitality Management. $14,3,325-338$. 
Gu, Zheng and Caneen, Jeff. (1996). The Utility of Two Pricing Models. Presentation to the Annual Symposium of The Association of Hospitality Financial Management Educators. New York, NY.

Jauncey, Stuart et. al. (1995). The Meaning and Management of Yield in Hotels. International Journal of Contemporary Hospitality Management. I, 4, 23-26.

Jones, Peter. (1992). Yield Management: Putting People in the Big Picture. Cornell Hotel \& Restaurant Administration Quarterly. 33, 1, 89-95. Kimes, Sheryl E. (1989). The Basics of Yield Management. The Cornell Hotel \& Restaurant Administration Quarterly 30, $3,14-19$.

Kimes, Sheryl E. (1990). Yield Management: A Tool for Capacity-Constrained Service Firms. Journal of Operations Management $8,4,348-363$.

Kimes, Sheryl E. (1994). Perceived Eairness of Yield Management. Cornell Hotel \& Restaurant Administration Ouarterly. 35, 1, 22-29. Ladany, Sp (1996). Optimal Market Segmentation of Hotel Rooms - The Non-linear Case. Omega, International Journal of Management Science 24, 1, 29-36. 
Lewis, R.C. and Roan, C. (1986). Selling What You Promote. The Cornel I Hotel \& Restaurant Administration Ouarterly. 27, 2, 13-15.

Lieberman, Warren H. (1993). Debunking the Myths of Yield Management. The Cornell Hotel \& Restaurant Administration Quarterly $34,1,34-41$.

Nykiel, R. (I989). 1990's: Decade of Yield Management. Presented at the Yield Management Multi-Industry Conference. Charlotte, NC.

Orkin, Eric B. (1988). Boosting Your Bottom Line With Yield Management. Cornell Hotel \& Restaurant Administration Quarterly $28,4,52-56$. Orkin, Eric B. (1990). Strategies for Managing Transient Rates. The Cornell Hotel \& Restaurant Administration Quarterly. 30, 1, 35-39. Orkin, Eric B. (1992). Yield Management. Cornell Hotel \& Restaurant Administration Ouarterly. $33,1$. Orkin, Eric B. (1992). How Can I Think About Yield Management Systems At A Time Like This? Hotel \& Resort Industry. 15 No 6 . PKE Consulting. (1995). Trends In The Hotel Industry. Pridgen, D. (1988). Consumer Protection and the Law. New York: Clark Boardman Co. 
Quain, William J. (1992). Analyzing Sales-Mix Profitability. Cornell Hotel \& Restaurant Administration Ouarterly. 33, $2,56-62$.

Reed, Dan. (1993). The American Eagle: The Ascent of Bob Crandall and American Airlines. New York: St. Martin's Press.

Relihan, Walter J. III. (1989). The Yield-Management Approach to Hotel-Room Pricing. The Cornell Hotel \&

Restaurant Administration Quarterly. 29, 2, 40-45. Russo, Joseph A. Jr. (1991). Variance Analysis: Evaluating

Hotel Room Sales. Cornell Hotel \& Restaurant

Administration Quarterly. 31, 4, 60-65. Shaw, Margaret. (1992). Positioning and Price: Merging Theory, Strategy, and Tactics.Hospitality Research Journal. 15, 2, 31-39. Shearman, Philip. (1992). The Balancing Act: Soft Yields, Hard Battles. Airline Business. Yearbook. 17t. Sheel, Atul. (1994). Marketing Implications of the Threshold Approach to Yield Management. Journal of Hospitality \& Leisure Marketing. 2, 1, 27-41. Smith Travel Research. (1995). Report For The Year 1994: Hotel Operating Statistics. 
Toh, R. (1986). Coping With No-Shows, Late Cancellations and OverSales: American Hotels Out-Do The Airlines.

International Journal of Hospitality Management. 5,3 , $121-125$.

Tunison, Larry Ronald. (1992). How to Put Value in Yield

Management. Lodging Magazine. 18, 1, 36t.

Varian, Hal R. (1996). Differential Pricing and Efficiency.

Working Paper: University of California at Berkeley.

Wardell, David. (1989). Yield Management: Understanding and

Exploiting It. Travel Weekley, March 20,75-76.

Weatherford, Lawrence R. and Bodily, Samuel E. (1992). A

Taxonomy And Research Overview of Perishable Asset

Management: Yield Management, Overbooking, And Pricing.

Operations Research. 40, 5, 831-843.

Wilson, Robert H. (1992). Combining Hotel Promotions,

Discount Packages, and Yield Management Systems: Make

Sure It's Legal. Hospitality Research Journal. 15, 2, $21-39$.

Wilson, Robert H., Enghagen, Linda K. and Sharma, Prashant.

(1994). Overbooking: The Practice And The Law.

Hespitality Research Journal. 17, 2, 93-105. 